\title{
Age matters: substrate-specific colonization patterns of benthic invertebrates on installed large wood
}

\author{
Florian Dossi [ - Patrick Leitner • Wolfram Graf
}

Received: 24 December 2019/Accepted: 23 April 2020/Published online: 6 May 2020

(C) The Author(s) 2020

\begin{abstract}
Large wood (LW) is an indispensable element in riverine ecosystems, especially in lower river parts. The presence of LW significantly shapes local hydraulics, morphology, the nutrient budget; promotes overall river dynamics; and additionally presents a unique habitat for numerous benthic invertebrate species. Therefore, $\mathrm{LW}$ is recognized as valuable asset for river restoration measures. Experiences from previous projects show that ecological responses on LW implementation measures vary greatly. That complicates comparisons and estimations on the success of planned measures. Methodological inconsistencies and thus reduced transferability of the results is one major issue. Additionally, wood quality aspects are suspected to be important factors affecting benthic invertebrate colonization patterns. The focus of this study is therefore to consistently assess the ecological significance of installed LW and concrete samples of similar size and shape in terms of benthic invertebrate colonization and to further test, if the condition of wood affects the benthic invertebrate colonization.
\end{abstract}

Handling Editor: Télesphore Sime-Ngando.

F. Dossi $(\bowtie) \cdot$ P. Leitner · W. Graf

IHG - Institute of Hydrobiology and Aquatic Ecosystem

Management, BOKU - University of Natural Resources

and Life Sciences, Gregor-Mendel-Strasse 33,

1180 Vienna, Austria

e-mail: florian.dossi@boku.ac.at
Our results show that (1) installed LW serves as an abundantly and heterogeneously colonized habitat, (2) the state of decay of LW pieces significantly affects benthic invertebrate colonization in terms of density and diversity and (3) even rare or threatened taxa closely associated to LW were abundantly present on the installed logs, emphasizing the suitability of the chosen approach.

Keywords Macroinvertebrates $\cdot$ Xylal $\cdot$ State of decay $\cdot$ River gradient $\cdot$ LW $\cdot$ Wood condition

\section{Introduction}

Large wood (LW) is a key component of natural river ecosystems. Previous studies have already stressed the beneficial effects of instream wood structures on local river hydraulics (e.g., Shields et al. 2001; Mutz 2003; Manners et al. 2007), hydromorphology (e.g., Gurnell et al. 1995, Kail et al. 2007, Blanckaert et al. 2014), nutrient balance (e.g., Bilby and Bisson 1998; Gurnell et al. 2005; Flores et al. 2011) and habitat diversity (e.g., Dudley and Anderson 1982; Hering and Reich 1997). Submerged LW provides essential habitats which are existential for many xylobiont species (Anderson et al. 1978; Hoffmann and Hering 2000) and are of increasing importance along the river course (Dossi et al. 2018). LW further offers vital aquatic- 
terrestrial interface areas and oviposition sites, significantly promoting the reproductive success of merolimnic invertebrate species (Dudley and Anderson 1982; Sweeney 1993; Hoffmann and Hering 2000). Due to the wide variety of beneficial aspects, LW is known to generally promote the density and diversity of fish and aquatic invertebrate species (e.g., Dudley and Anderson 1982; Copp 1992; Hering and Reich 1997; Hoffmann and Hering 2000; Pilotto et al. 2014, 2016) and therefore presents a valuable and cost-effective asset for river restoration measures, especially given the large amount of morphologically degraded river sections and comparably low costs to conventional measures (Kail and Hering 2005; Kail et al. 2007). Rough estimates assume that even in densely populated areas such as Central Europe, approximately one-third of the degraded river sections could be restored by reintroducing LW structures (Kail and Hering 2005).

A profound understanding of LW and ecosystem interactions is a prerequisite for efficient implementations in river management practices. Even though LW and its function in river ecosystems have been extensively investigated, knowledge gaps and therefore implementation shortcomings still persist. Kail et al. (2007) evaluated 50 restoration projects in Germany and Austria involving LW placement and found that only approximately 58\% were successful. The authors concluded that the key to success lied in the consideration of site-specific characteristics. Hence, profound knowledge on river type specific wood characteristics is one important criterion to promote the success of measures. One challenge, hard to come by, is the lack of knowledge of the pristine state of LW and related ecological aspects in many European streams due to the long history of active wood removal (Hering and Reich 1997; Hering et al. 2000). Additional studies in different areas with remaining intact riparian vegetation and at least near-natural LW dynamics are therefore of utter most importance to improve the understanding of LW and biota interactions.

Benke and Wallace (2003) called attention to additional difficulties regarding comparability and transferability of results from different studies. Fundamental information such as reported invertebrate densities span wide apart from several hundred (e.g., O'Connor 1992; Rabeni and Hoel 2000) to many (ten-) thousands of individuals per square meter (e.g.,
Smith and Smock 1992; Benke 1998). Besides natural fluctuations of densities due to riverine characteristics on local up to regional scales or methodological inconsistencies, especially regarding the quantification of LW pieces and related individual densities, variations due to differing wood quality aspects, such as hardness, species and condition, were discussed as potentially important factors (Benke and Wallace 2003). That suggests a type specific colonization of wood substrate, especially considering general substrate selection processes of invertebrates substantially determining species richness, composition and density in freshwater ecosystems (Minshall 1984). Wood quality aspects were focused by only a limited number of studies, but most results indicate that the type and quality of instream LW affect invertebrate colonization patterns (e.g., Anderson et al. 1978; Kaufman and King 1987; Magoulick 1998; McKie and Cranston 1998; O’Connor 1991; Spänhoff et al. 2000).

The aim of this study is therefore (1) to consistently assess the general ecological value of LW structures of installed wood and concrete samples of comparable size and shape in terms of species richness and density, (2) to investigate colonization patterns based on the condition of the introduced LW pieces and (3) to test if the results are consistent within different river stretches along the longitudinal gradient of a medium-sized lowland river in Austria.

\section{Materials and methods}

\section{Study sites}

Four sites along the Lafnitz River have been investigated. The Lafnitz River is one of the last mediumsized meandering rivers in the Central Europe with near-natural flow-regime and morphodynamics, riparian vegetation and LW accumulations along large parts of its course. It is therefore well suited to study the importance of LW and its interactions with biota. The Lafnitz lies within the Danube catchment, located in the southeastern part of Austria (Fig. 1). The river course has an approximate length of $112 \mathrm{~km}$ and drains into the Raab River, in Hungary. The Lafnitz River has a catchment size of approximately $2000 \mathrm{~km}^{2}$ at the border of Austria, making it the 13th largest river in Austria (BMLFUW 2002; Cejka et al. 2005). The spring is located in the federal state of 


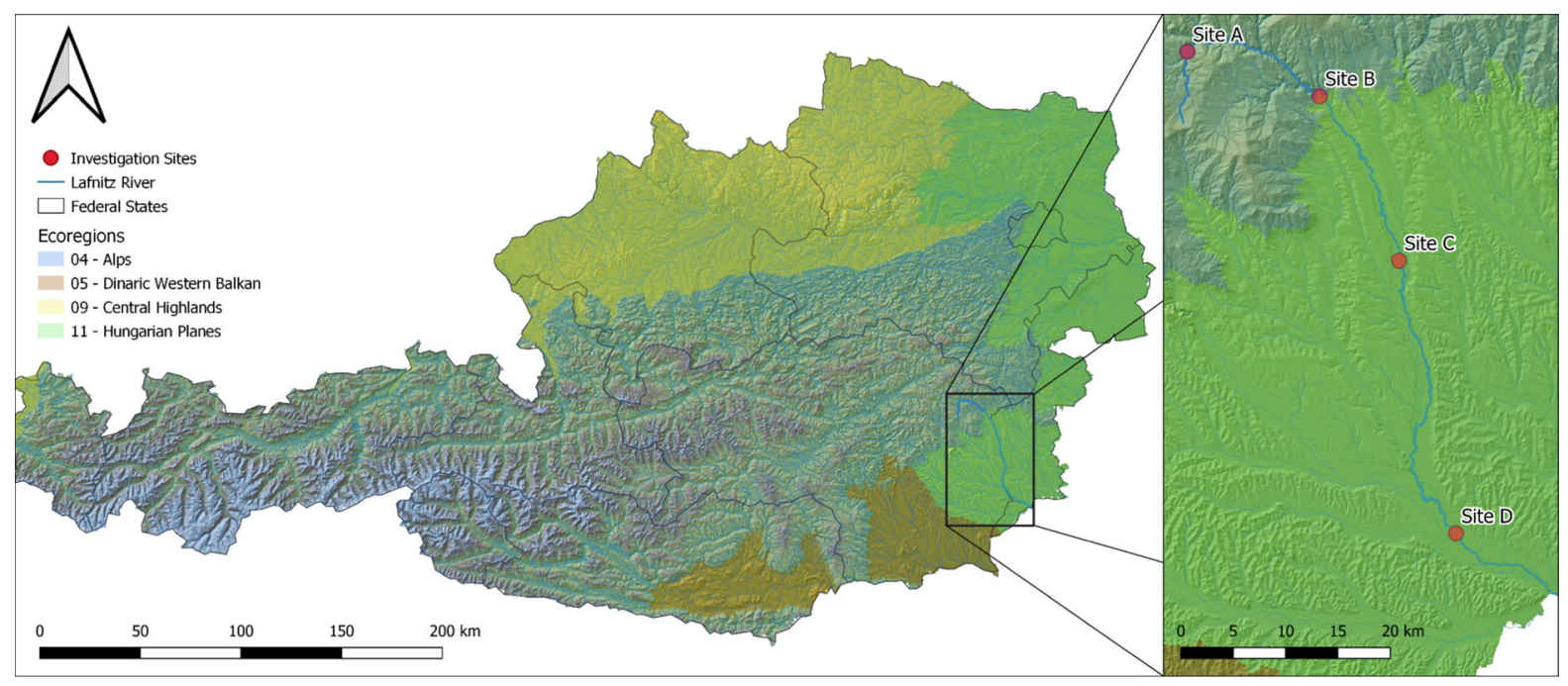

Fig. 1 Overview of the project area and location of the Lafnitz River in Austria (left) and location of the investigation sites along the river course (right); overlay: Ecoregions according to Illies (1978)

Styria and originates at an altitude of $940 \mathrm{~m}$ above sea level (m a.s.l.). Following Illies (1978), the first 36 river kilometers are situated in the ecoregion 4-Alps, whereas the following section lies in ecoregion 11-Hungarian Plains (Fig. 1). The mean annual discharge of the Lafnitz River spans from $2.6 \mathrm{~m}^{3} / \mathrm{s}$ in the upper section (near Site A) to approximately $6.3 \mathrm{~m}^{3} / \mathrm{s}$ in the lower section near the town Dobersdorf (near Site E).

The sampling sites were chosen to cover a variety of different river characteristics along the longitudinal gradient to (1) allow general statements on the potential ecological benefits of installed wood structures as well as to (2) assess possible variations in different river sections. At all four sites naturally deposited large wood accumulations were present to ensure a comparable colonization potential.

Samples have been taken at four sites along the river course (see Table 1), whereas the most upstream site is located at $648 \mathrm{~m}$ a.s.l. and the most downstream site at $244 \mathrm{~m}$ a.s.l. The sites were chosen based on significant changes of river characteristics such as slope, discharge (stream order according to Strahler (1957)), substrate composition and morphological characteristics. Figure 1 gives an overview of the site locations along the river course. Site-specific characteristics are shown in Table 1.

Abiotic characteristics at each site including mean flow velocity, mean water depth and dominant grain size at each site were assessed in March 2014 prior to the installation of the samples. Mean flow velocities and water depths were derived from averaged transect measurements. Grain size distribution were based on the choriotope assessment (Multi-Habitat-SamplingMethod (MHS), AQEM Consortium 2002).

Sample characteristics, sampling design and laboratory work

For this colonization experiment three different types of substrate, comparable in size, were installed at each sampling site: (1) concrete bars, (2) fresh logs and (3) rotten logs (Figs. 2, 3).

The concrete bars were used to mimic lithal substrates of comparable size and shape to the logs. The dimensions of each piece were $50 \mathrm{~cm} \times 5 \mathrm{~cm} \times$ $20 \mathrm{~cm}$ (length $\times$ width $\times$ height). In each concrete bar, a whole was drilled and a rope was attached to be fixed at nearby trees (see Figs. 4, 5).

All xylal substrate samples (fresh and rotten) originate from the Lafnitz River and were sampled in February 2014 near the village of Neustift, in the middle section of the river. To ensure comparability, only previously submerged logs with a diameter between $200 \mathrm{~mm}$ and $300 \mathrm{~mm}$ were used in this study. Each $\log$ was cut to a length of $630 \mathrm{~mm}$ and analogous to the concrete bars; a hole was drilled in each sample log and a rope was attached to fix the log 
Table 1 Overview of site characteristics including altitude (meters above sea level), distance from spring $(\mathrm{km})$, mean river slope $(\%)$, dominant grain size $(\mathrm{cm})$, Strahler number (Strahler
1957), average water depth (m), average flow velocity $(\mathrm{m} / \mathrm{s})$ and average river width $(\mathrm{m})$

\begin{tabular}{lllllllll}
\hline Site & $\begin{array}{l}\text { Altitude } \\
(\mathrm{m} \text { asl })\end{array}$ & $\begin{array}{l}\text { Distance from } \\
\text { Spring }(\mathrm{km})\end{array}$ & $\begin{array}{l}\text { Slope } \\
(\%)\end{array}$ & $\begin{array}{l}\text { Dominant grain } \\
\text { size }(\mathrm{cm})\end{array}$ & $\begin{array}{l}\text { Strahler } \\
\text { Number }\end{array}$ & $\begin{array}{l}\text { Average water } \\
\text { depth }(\mathrm{m})\end{array}$ & $\begin{array}{l}\text { Flow } \\
\text { Velocity }(\mathrm{m} / \\
\text { s) }\end{array}$ & $\begin{array}{l}\text { Average River } \\
\text { width }(\mathrm{m})\end{array}$ \\
\hline A & 648 & 8.7 & 1.7 & $6.3-20$ & 4 & 0.2 & 0.3 & 8 \\
B & 438 & 26.1 & 0.9 & $6.3-40$ & 5 & 0.3 & 0.6 & 15 \\
C & 324 & 52.1 & 0.3 & $2-6.3$ & 5 & 0.5 & 0.3 & $10-20$ \\
D & 244 & 100.4 & $<0.1$ & $2-6.3$ & 6 & 0.6 & 0.35 & 20 \\
\hline
\end{tabular}
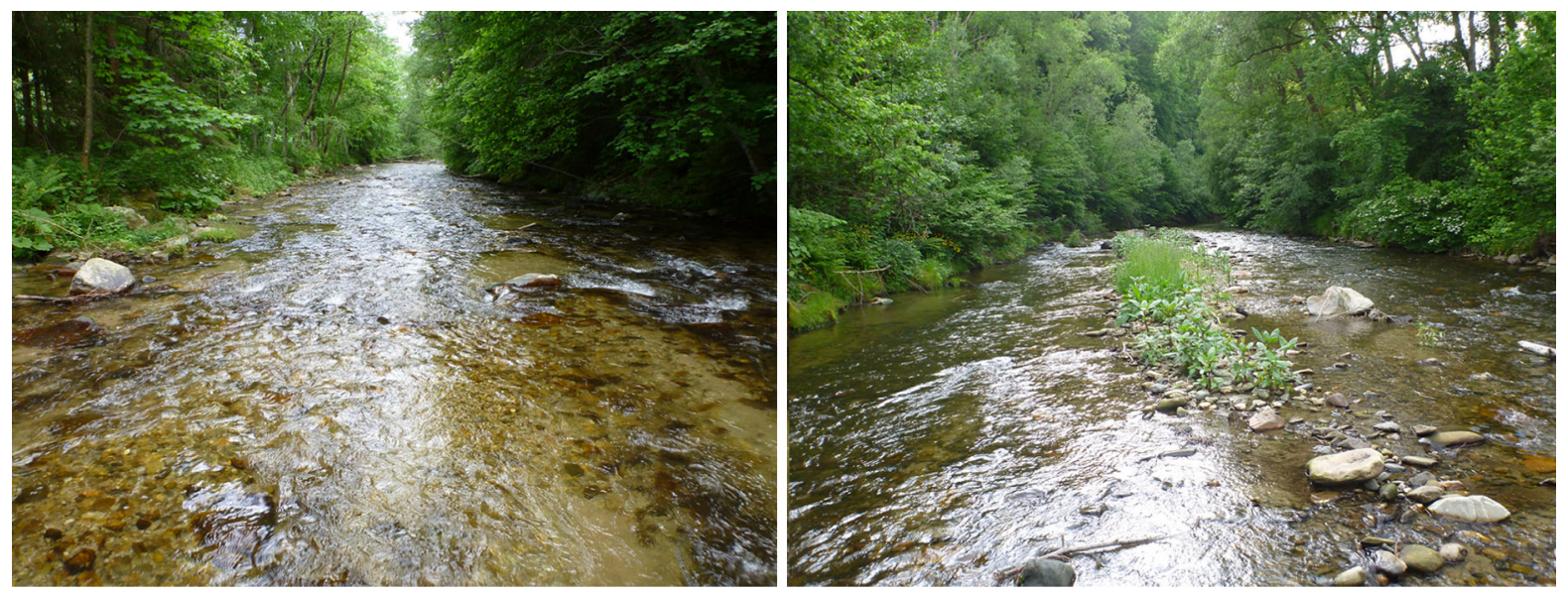

Fig. 2 Picture of the Lafnitz River at site A (left) and site B (right)
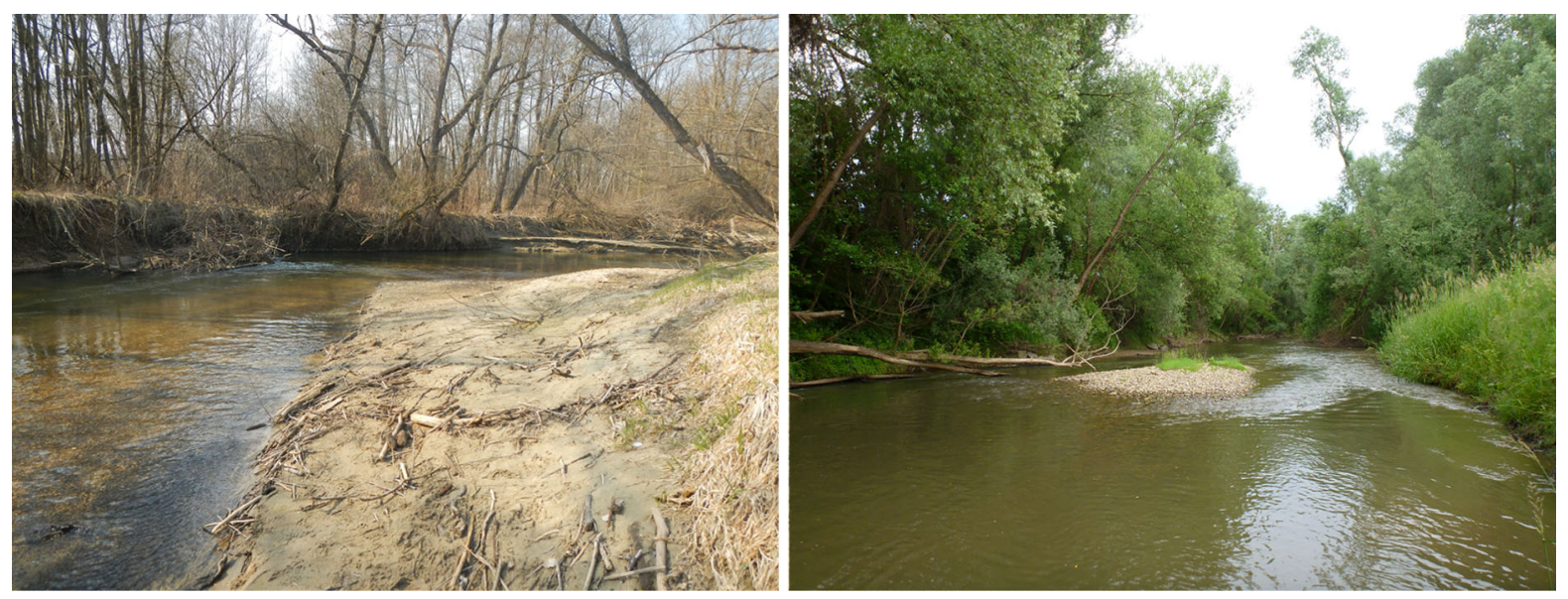

Fig. 3 Picture of the Lafnitz River at site C (left) and site D (right)

at the chosen sites (see Fig. 4). All sampled logs were classified into the categories "rotten" and "fresh" on site (examples see Fig. 6). Wood classification was based on the summarized decay categories of Robinson and Beschta (1990) (class 1-3: fresh; class 4-5: rotten) and Grette (1985) (class 1-4 fresh; class 5-6: 


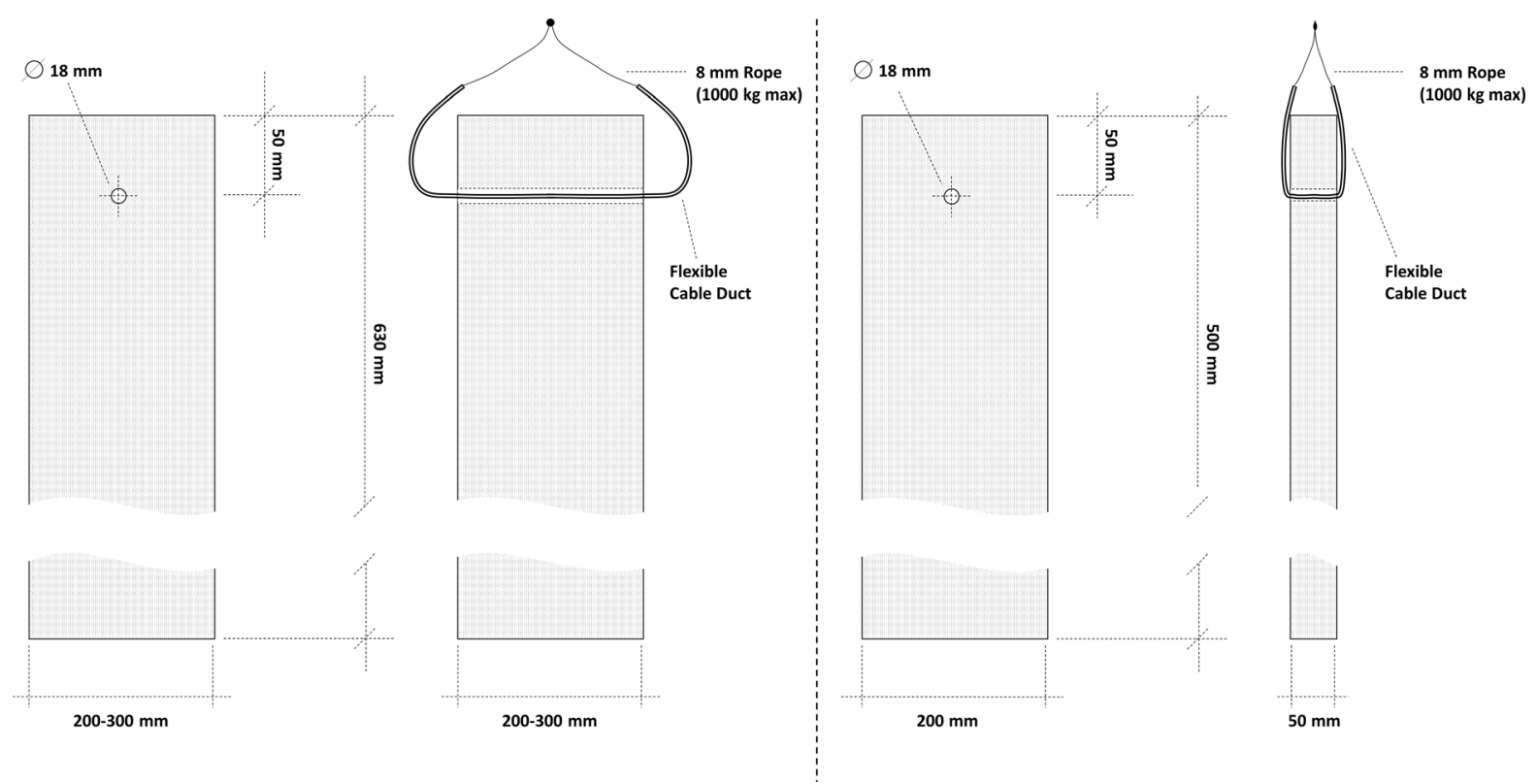

Fig. 4 Sample schematics and dimensions for fresh and rotten logs (left) and concrete samples (right)

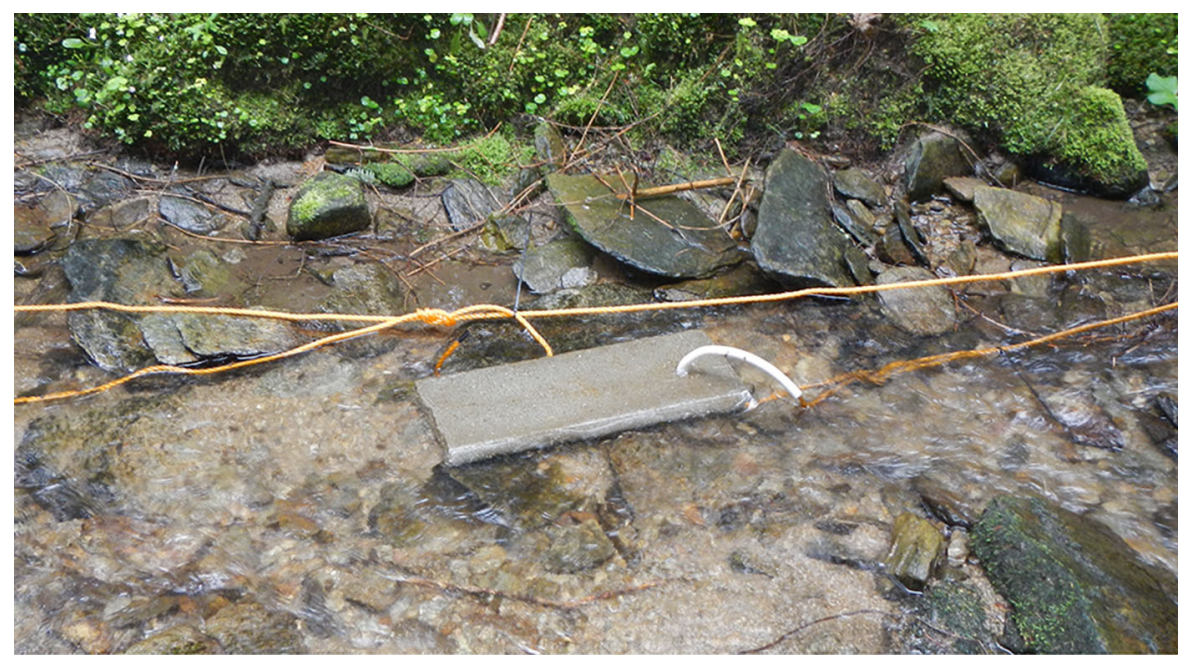

Fig. 5 Example of one installed concrete bar at site A

rotten). Details on the classification characteristics of wood pieces are shown in Annex see Table 5, 6. Length, width and volume of each LW piece was measured, and the surface area was calculated using the formula of a simplified shape of a truncated cone:

$S=r^{2} * \pi+\pi * R^{2}+\pi * h *(r+R)$

where $S=$ surface area, $r=$ radius $1, R=$ radius 2 , $h=$ sample height.
The surface area of the sampled LW pieces varied between $0.16 \mathrm{~m}^{2}$ and $0.32 \mathrm{~m}^{2}$. The volume of each LW piece was measured in an overflow tank and varied between $2.8 \mathrm{dm}^{3}$ and $10.2 \mathrm{dm}^{3}$. In total, there were 24 wood samples, corresponding to a total surface area of approximately $5.2 \mathrm{~m}^{2}$ (12 rotten logs: $2.5 \mathrm{~m}^{2} ; 12$ fresh logs: $2.7 \mathrm{~m}^{2}$ ). All wood sample characteristics are summarized in Table 2. After classification and preparation of the samples, all wood samples were rinsed, cleaned and carefully examined 

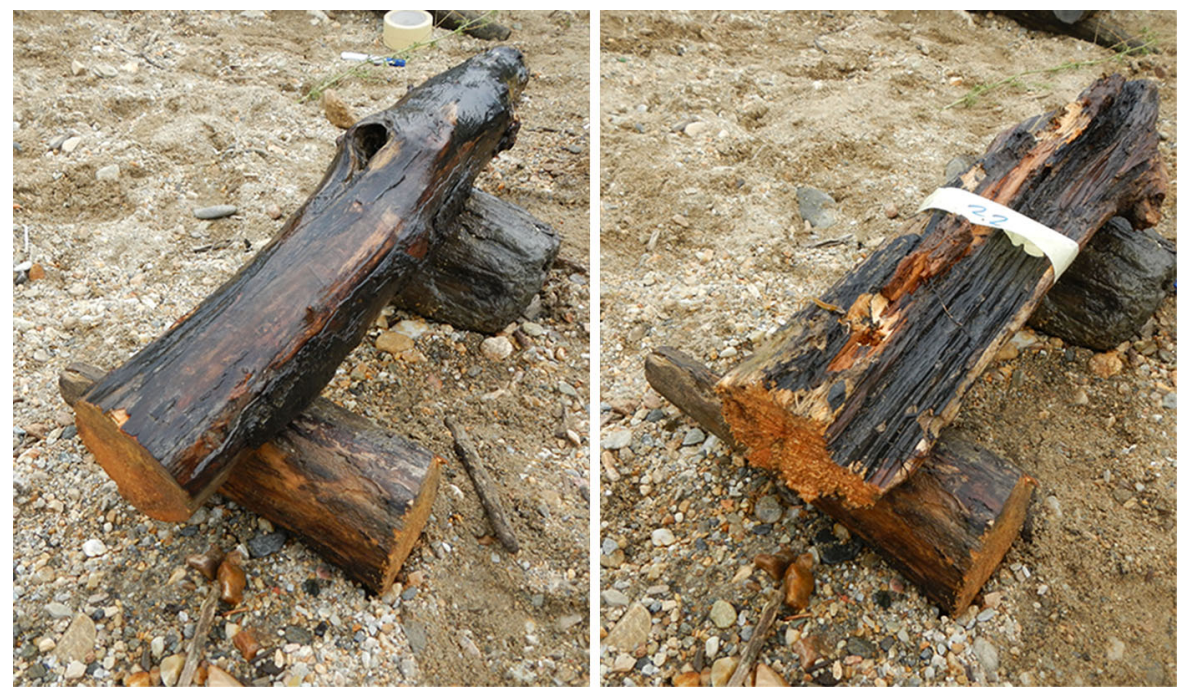

Fig. 6 Example of fresh (left) and rotten logs (right) installed at the Lafnitz River

for remaining organisms to ensure a comparable precolonization state of all samples. The logs were then stored in black plastic bags until installation.

The logs and concrete bars were installed in a similar manner at each site. At each of the four sites, three concrete bars and six logs (three fresh/three rotten) were installed in early March 2014. Three long guiding ropes (approximately 15-20 m) were tied to riparian trees, and three substrate samples (either logs or concrete bars) were subsequently bound to each guiding rope. The allocation of logs and concrete bars on the guiding ropes was randomized, and all samples were installed in comparable orientations, parallel to the flow. However, a slight displacement or motion of the samples was possible. The location and orientation of the guiding ropes was chosen to ensure comparable habitat characteristics for each sample within each site (e.g., flow velocity, surrounding substrate composition).

Details on the habitat parameters at each concrete bar or $\log$ are given in Table 2. All single logs and concrete bars were installed with a minimum distance of $2 \mathrm{~m}$ to each other to allow undisturbed sampling conditions at each log or concrete bar. To ensure comparable colonization potentials, all samples had contact with the river bottom.

Sampling was performed in spring 2014 and 2015. To ensure comparable exposition times, all logs and concrete bars were cleaned and carefully examined 6 weeks prior to each sampling run. All attached organisms were removed, and each log or concrete bar was subsequently reintroduced to the river. Benthic samples were taken on three different dates in April 2014, June 2014 and March 2015. All samples were taken within 1 day. Due to the long exposition time and the high morphodynamics at the Lafnitz River, not all samples were consistently available for analysis. Single $\operatorname{logs}$ or concrete bars which occasionally stranded or were entirely covered with sediments were excluded from subsequent analysis (Details see Table 2).

Sampling was performed with a standardized $500-\mu \mathrm{m}$ mesh-size kick-net with a frame size of $25 \times 25 \mathrm{~cm}$ (surface area per single sample: $0.0625 \mathrm{~m}^{2}$ ) and a net length of $1.2 \mathrm{~m}$. Prior to sampling, all LW pieces were carefully put into the kick-net to avoid organisms from drifting. Benthic invertebrates were then carefully brushed and washed from the LW piece into the kick net. All organisms were preserved with formaldehyde (4\%) (Table 3).

The Screening-Taxa list (Ofenböck et al. 2010) was used as a basis for identification. In many cases Ephemeroptera, Plecoptera and Trichoptera taxa could be identified to a lower taxonomic level (genus/ species), whereas Diptera taxa were mainly identified to family level. Oligochaeta were not identified further. All taxa were counted and weighed (wet weight). Specimens were then fixed in $70 \%$ ethanol and stored. 
Table 2 Overview of the sample characteristics including sample ID, the site, volume $\left(\mathrm{dm}^{3}\right)$, surface $\left(\mathrm{cm}^{2}\right)$, the state (ffresh, r-rotten, c-concrete), the flow velocity (mean flow velocity at exact sampling point in $\mathrm{m} / \mathrm{s}$ ), dominant substrate at exact sampling point and the availability (only fully submerged samples from each sampling date were considered for analysis) of samples at the each sampling date (1-23.04.14, 2-28.06.14, 3-18.03.15)

\begin{tabular}{|c|c|c|c|c|c|c|c|c|c|}
\hline Sample ID & Site & Volume $\left(\mathrm{dm}^{3}\right)$ & Surface $\left(\mathrm{cm}^{2}\right)$ & State & Flow velocity $(\mathrm{m} / \mathrm{s})$ & Substrate & 1 & 2 & 3 \\
\hline W01 & A & 4.8 & 2161 & $\mathrm{r}$ & 0.3 & Psammal & + & + & + \\
\hline W02 & A & 5.1 & 2131 & $\mathrm{r}$ & 0.3 & Microlithal & + & + & + \\
\hline W03 & A & 7.2 & 2416 & $\mathrm{r}$ & 0.1 & Psammal & + & + & + \\
\hline W04 & A & 3.9 & 1981 & $\mathrm{f}$ & 0.4 & Psammal/Akal & + & + & + \\
\hline W05 & A & 6.1 & 2462 & $\mathrm{f}$ & 0.2 & Psammal & + & + & + \\
\hline W06 & A & 10.2 & 3178 & $\mathrm{f}$ & 0.3 & Psammal & + & + & + \\
\hline $\mathrm{C} 01$ & A & 5 & 2700 & $\mathrm{c}$ & 0.7 & Akal/Microlithal & + & + & + \\
\hline $\mathrm{C} 02$ & A & 5 & 2700 & $\mathrm{c}$ & 0.1 & Psammal & + & + & + \\
\hline $\mathrm{C} 03$ & A & 5 & 2700 & $\mathrm{c}$ & 0.7 & Akal/Microlithal & - & + & + \\
\hline W07 & $\mathrm{B}$ & 4.5 & 2027 & $\mathrm{r}$ & 0.8 & Microlithal & + & + & + \\
\hline W08 & B & 4 & 1911 & $\mathrm{r}$ & 0.8 & Microlithal & + & + & + \\
\hline W09 & $\mathrm{B}$ & 3.9 & 1880 & $\mathrm{r}$ & 0.8 & Microlithal & + & + & + \\
\hline W10 & $\mathrm{B}$ & 5.2 & 2314 & $\mathrm{f}$ & 0.8 & Akal/microlithal & + & + & + \\
\hline W11 & $\mathrm{B}$ & 7 & 2594 & $\mathrm{f}$ & 0.4 & Microlithal & + & + & + \\
\hline W12 & $\mathrm{B}$ & 4.9 & 2123 & $\mathrm{f}$ & 0.7 & Akal/microlithal & + & + & + \\
\hline $\mathrm{C} 04$ & $\mathrm{~B}$ & 5 & 2700 & $\mathrm{c}$ & 0.8 & Akal/microlithal & + & + & + \\
\hline $\mathrm{C} 05$ & $\mathrm{~B}$ & 5 & 2700 & $\mathrm{c}$ & 0.7 & Akal/microlithal & - & + & + \\
\hline $\mathrm{C} 06$ & $\mathrm{~B}$ & 5 & 2700 & $\mathrm{c}$ & 0.7 & Akal/microlithal & + & + & + \\
\hline W13 & $\mathrm{C}$ & 6 & 2350 & $\mathrm{r}$ & 0.2 & Psammal & - & + & + \\
\hline W14 & $\mathrm{C}$ & 5.9 & 2332 & $\mathrm{r}$ & 0.5 & Akal/psammal & + & - & + \\
\hline W15 & $\mathrm{C}$ & 4 & 1927 & $\mathrm{r}$ & 0.3 & Psammal & + & + & + \\
\hline W16 & $\mathrm{C}$ & 7.1 & 2600 & $\mathrm{f}$ & 0.2 & Psammal & - & + & + \\
\hline W17 & $\mathrm{C}$ & 2.8 & 1678 & $\mathrm{f}$ & 0.3 & Psammal & + & + & + \\
\hline W18 & $\mathrm{C}$ & 4.2 & 1952 & $\mathrm{f}$ & 0.2 & Psammal & + & + & + \\
\hline $\mathrm{C} 07$ & $\mathrm{C}$ & 5 & 2700 & $\mathrm{c}$ & 0.4 & Akal & - & + & + \\
\hline $\mathrm{C} 08$ & $\mathrm{C}$ & 5 & 2700 & $\mathrm{c}$ & 0.5 & Akal/microlithal & + & - & + \\
\hline $\mathrm{C} 09$ & $\mathrm{C}$ & 5 & 2700 & $\mathrm{c}$ & 0.5 & Akal & + & - & + \\
\hline W19 & $\mathrm{D}$ & 3.6 & 1811 & $\mathrm{r}$ & 0.6 & Psammal/akal & + & + & + \\
\hline W20 & $\mathrm{D}$ & 4 & 1898 & $\mathrm{r}$ & 0.6 & Psammal/akal & + & + & + \\
\hline W21 & $\mathrm{D}$ & 3 & 1629 & $\mathrm{r}$ & 0.6 & Psammal/akal & + & + & + \\
\hline W22 & $\mathrm{D}$ & 4.8 & 2129 & $\mathrm{f}$ & 0.6 & Psammal/akal & + & + & + \\
\hline W23 & $\mathrm{D}$ & 6.8 & 2559 & $\mathrm{f}$ & 0.6 & Psammal/akal & + & + & + \\
\hline W24 & $\mathrm{D}$ & 4.1 & 1944 & $\mathrm{f}$ & 0.6 & Psammal/akal & + & + & + \\
\hline $\mathrm{C} 10$ & $\mathrm{D}$ & 5 & 2700 & $\mathrm{c}$ & 0.6 & Psammal/akal & + & + & - \\
\hline $\mathrm{C} 12$ & $\mathrm{D}$ & 5 & 2700 & $\mathrm{c}$ & 0.6 & Psammal/akal & + & + & + \\
\hline $\mathrm{C} 13$ & $\mathrm{D}$ & 5 & 2700 & $\mathrm{c}$ & 0.6 & Psammal/akal & + & + & + \\
\hline
\end{tabular}

Data analysis

Statistical analyses were performed with the Software R-Studio 1.1.456. The Levene's test was applied to test equality of variances between the substrate groups and the Shapiro-Wilk Test to test on normality of the data. All abundance and biomass data (from all substrates) were converted to densities (Ind $/ \mathrm{m}^{2}$ ). 
Table 3 Overview of the total number of specimen, taxa and families observed at each site and substrate type

\begin{tabular}{lcccc}
\hline & A & B & C & D \\
\hline No of specimen & & & & \\
Concrete & 3338 & 2578 & 796 & 1918 \\
Fresh & 2221 & 3270 & 3887 & 3562 \\
Rotten & 3154 & 5819 & 6703 & 4746 \\
No of taxa & & & & \\
Concrete & 33 & 29 & 32 & 42 \\
Fresh & 36 & 36 & 34 & 48 \\
Rotten & 42 & 49 & 43 & 47 \\
No of families & & & & \\
Concrete & 22 & 19 & 22 & 27 \\
Fresh & 27 & 24 & 23 & 32 \\
Rotten & 30 & 30 & 23 & 31 \\
\hline
\end{tabular}

Abundances for cluster and NMDS analyses were log $(n+1)$ or presence/absence transformed. For cluster analysis "Bray-Curtis" distance measure and "Ward.D2" linkage method was applied. NMDS analysis (Kruskal, 1964) was performed with "Sørensen (Bray-Curtis)" distance measure.

The affinity of species or taxa to a particular substrate type was performed combining two different methods:

1. Identification of taxa exclusively present on one substrate type and

2. identification of taxa which were significantly more abundant on one substrate type based on the results of an "Indicator species Analysis (ISA). All taxa with an Indicator value (IV) $>25$ (Dufrene and Legendre 1997) and a $p$ value of $\leq 0.05$ were considered as significantly overrepresented on the corresponding substrate type.

This two-level approach was chosen in order to consider that even though some taxa significantly benefit from the presence of wood are not necessarily limited to wood as a habitat. The sole information on exclusive occurrences would therefore be insufficient.

\section{Results}

In total $\sim 43,000$ benthic invertebrate specimen and 108 taxa from 52 families and 12 orders were collected (see Annex in Table 7). The most abundant orders were Diptera ( 32\%; mainly Chironomidae), Crustacea ( 27\%; only Gammarus fossarum) and Trichoptera (22\%; mainly Limnephilidae). Ephemeroptera comprised a share of $\sim 13 \%$ and Plecoptera of $\sim 3 \%$. Benthic invertebrate species richness gradually increased along the river course from 49 taxa at site A to 71 taxa at site $\mathrm{D}$. Taxa richness per sample ranged from 4 to 27 taxa. Details on the number of specimens, taxa and families at each site and substrate type are summarized in Table 3.

Density and diversity differences

between substrate types

Benthic invertebrate colonization showed significant differences between the substrate types (see Fig. 7). Abundance, biomass and species richness were significantly higher (Wilcoxon test: $\alpha=0.01$ ) on wood samples (Ind/ $/ \mathrm{m}^{2}: \quad \mu=2436.9 \pm 241.3 ; \quad \mathrm{g} / \mathrm{m}^{2}: \quad \mu=31.7 \pm$ 5.5; No. of taxa: $\mu=15.5 \pm 0.6)$ compared to concrete samples $\left(\mathrm{Ind} / \mathrm{m}^{2}: \quad \mu=1102.2 \pm 139.0 ; \mathrm{g} / \mathrm{m}^{2}: \quad \mu=\right.$ $8.1 \pm 1.4$; No. of taxa: $\mu=11.8 \pm 0.6$ ). Wood sample showed a generally wider variation, as shown by the higher standard errors. Further, significant differences between fresh (Ind $/ \mathrm{m}^{2}: \quad \mu=1723.9 \pm 219.8 ; \mathrm{g} / \mathrm{m}^{2}$ : $\mu=23.7 \pm 4.8$; No. of taxa: $\mu=13.9 \pm 0.8)$ and rotten wood samples (Ind $/ \mathrm{m}^{2}: \quad \mu=3194.5 \pm 401.6 ; \mathrm{g} / \mathrm{m}^{2}$ : $\mu=40.2 \pm 10$; No. of taxa: $\mu=17.3 \pm 0.9$ ) were evident. Only biomass differences between fresh and rotten wood did not show significant results. Still, a consistent pattern with lowest benthic invertebrate density and diversity on concrete, followed by fresh wood and peak values on rotten wood, was clearly visible.

The most prominent density differences among the substrate types were found for Gammarus fossarum (concrete: $\mu=102.2 \mathrm{Ind} / \mathrm{m}^{2}$; fresh: $648 \mathrm{Ind} / \mathrm{m}^{2}$; rotten: $1086 \mathrm{Ind} / \mathrm{m}^{2}$ ) (see Fig. 8: left). Diptera (mainly represented by Chironomidae taxa) showed comparable densities on concrete bars $\left(487 \mathrm{Ind} / \mathrm{m}^{2}\right)$ and fresh $\operatorname{logs}\left(418 \mathrm{Ind} / \mathrm{m}^{2}\right)$ while being distinctly more abundant on rotten logs $\left(1206 \mathrm{Ind} / \mathrm{m}^{2}\right)$. Lowest Trichoptera densities were recorded on concrete $\left(167 \mathrm{Ind} / \mathrm{m}^{2}\right)$, followed by fresh $\left(433 \mathrm{Ind} / \mathrm{m}^{2}\right)$ and highest on rotten 

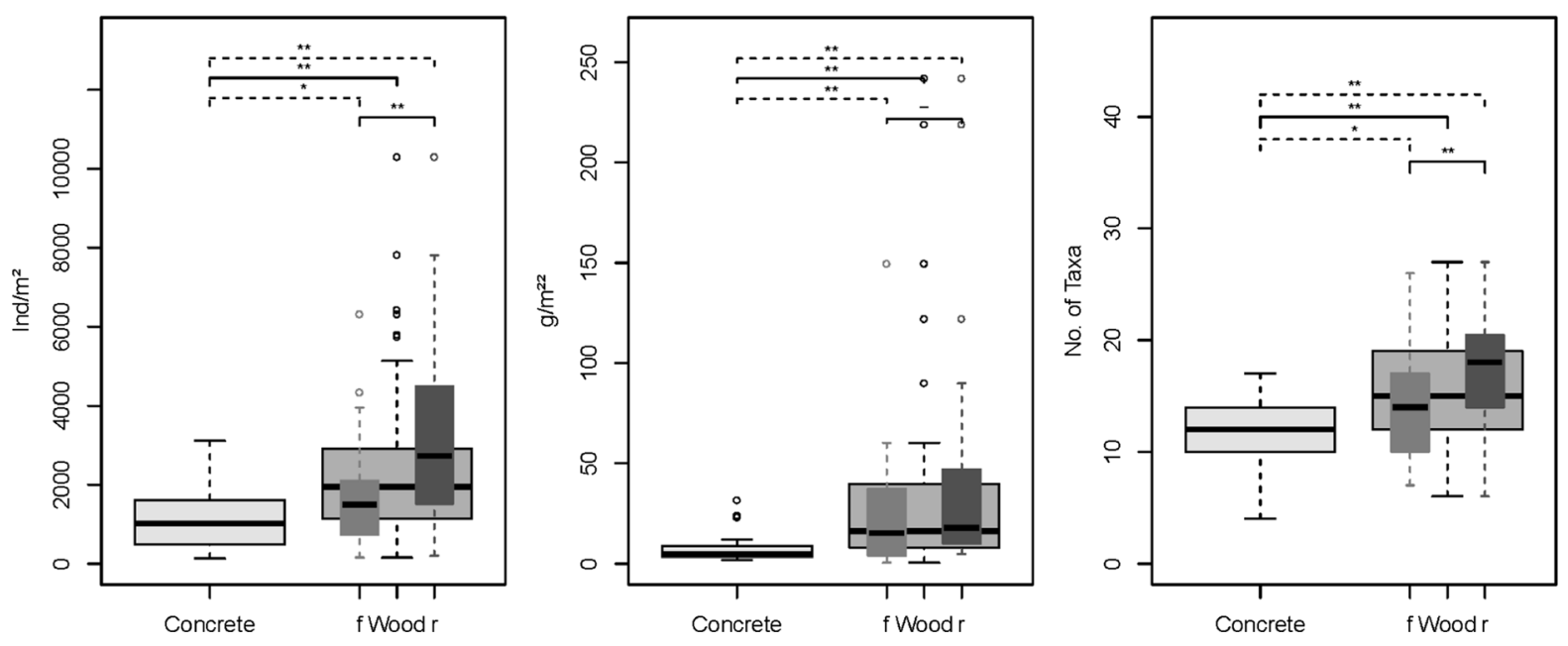

Fig. 7 Boxplot based on the number of individuals $/ \mathrm{m}^{2}$ (left), biomass $/ \mathrm{m}^{2}$ (middle) as well as the number of taxa (right) recorded at each single log or concrete bar; $\mathrm{f}-$ fresh wood, $\mathrm{r}$-rotten wood; $* p \leq 0.05, * * p \leq 0.01,-p \geq 0.05$
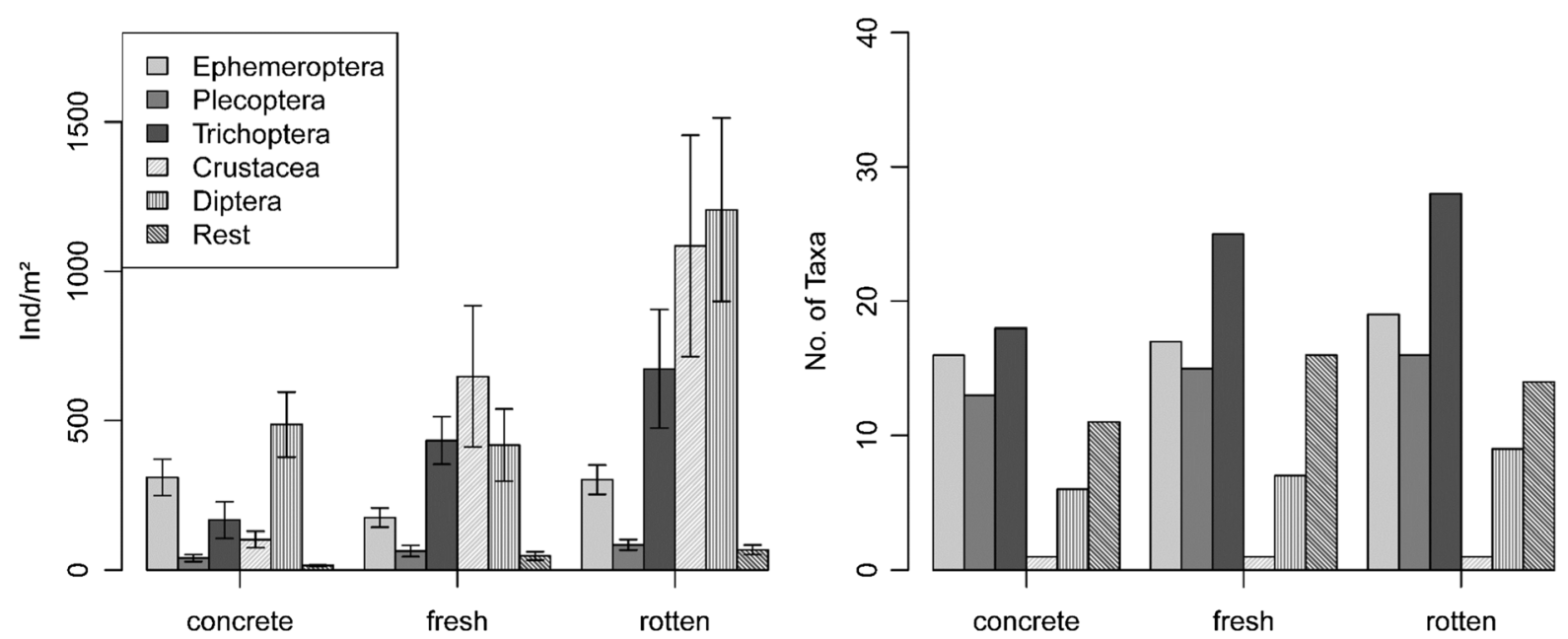

Fig. 8 Mean number of individuals of each order found on concrete bars (c), fresh (f) and rotten logs (r) with additional display of the standard error of the mean (left) and total number of taxa in each order (right)

$\operatorname{logs}\left(673 \mathrm{Ind} / \mathrm{m}^{2}\right)$. For Ephemeroptera and Plecoptera taxa no particular trend was visible. The number of taxa for all orders except for Crustacea (G. fossarum) showed a minor but consistent pattern as shown in Fig. 8: right. The number of taxa for Ephemeroptera, Plecoptera, Trichoptera and Diptera gradually increases from concrete bars to fresh and rotten logs (see Fig. 8: right).

Differences in species distribution between the substrate are well reflected in the number of substratespecific taxa (see Table 4). Considering all samples, three taxa were exclusively present on concrete bars (e.g., Ephemeroptera: Epeorus alpicola and
Trichoptera: Glossosoma sp.). In total, 39 taxa were only found on wood samples (e.g., Plecoptera: Agnetina elegantula and Coleoptera: Macronychus quadrituberculatus). A further differentiation between fresh and rotten wood samples showed nine taxa exclusively present on fresh (e.g., Trichoptera: Rhyacophila tristis and Silo pallipes) and 17 exclusively on rotten wood samples (e.g., Trichoptera Hydropsyche bulbifera and Lype phaeopa) (see Fig. 9: left). Results from each site and run separately reveal a comparable pattern to the overall analysis (see Fig. 9: middle). Lowest number of exclusive taxa were found on concrete $(\mu=2.7 \pm 0.6)$ followed by fresh- 

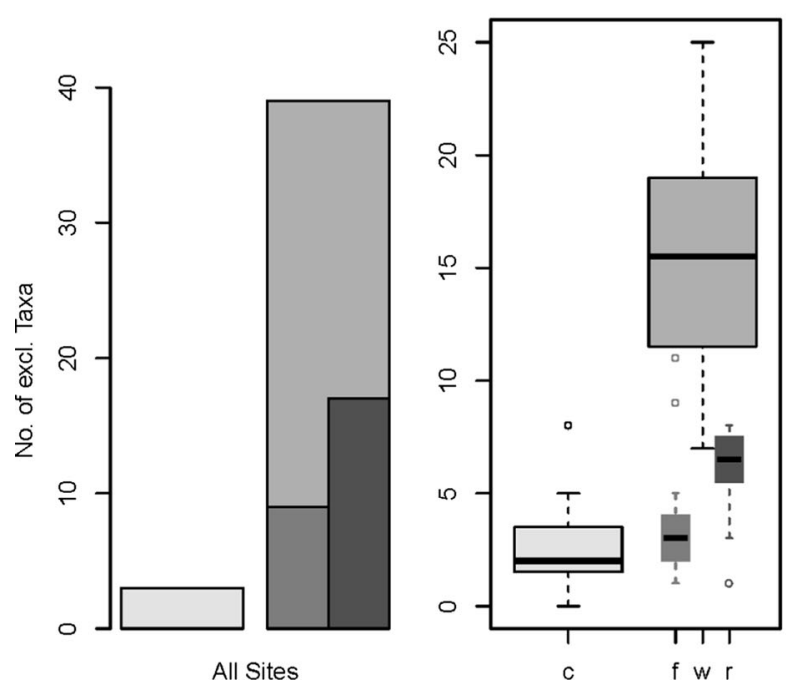

Fig. 9 Bar chart showing the number of exclusive taxa on each substrate type from all sites (Site A to Site C) (left); number of exclusive taxa on each substrate type for each single sampling

$(\mu=3.8 \pm 0.9) \quad$ and rotten wood samples $(\mu=6 \pm 0.6)$.

The results of the indicator species analysis are shown in Table 4. The analysis was performed based on different taxonomic resolutions (family, genus and species level), and results of all three taxonomic levels showed consistent results. Seven families were identified, mainly represented by one dominant taxon which was significantly more abundant on fresh and rotten wood, respectively (e.g., Trichoptera: Lepidostomatidae: Lepidostoma basale; Limnephilidae: Halesus sp., Rhyacophilidae: Rhyacophila s.str.sp.) and two families/genera significantly more abundant exclusively on rotten wood samples (Coleoptera: Hydraenidae: Hydraena sp.; Crustacea: Gammaridae: Gammarus fossarum). On genus/species level one additional taxon was found to be significantly more abundant on concrete samples (Plecoptera: Perlidae: Perla sp.) and one on fresh and rotten wood samples (Ephemeroptera: Heptageniidae: Heptagenia longicauda).

\section{Community composition}

Community analysis shows a clear separation of samples per site (see Fig. 11) indicating that sitespecific river characteristics are the predominant factors determining the benthic community. In addition, a distinct longitudinal pattern as well as

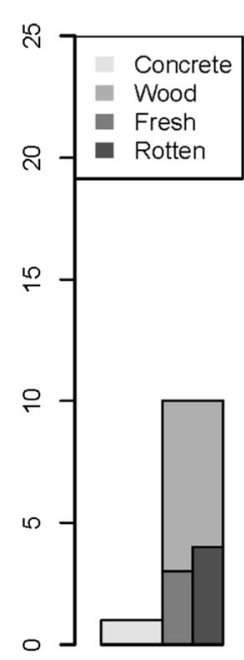

A

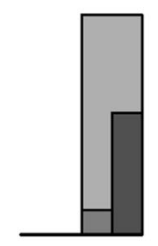

B

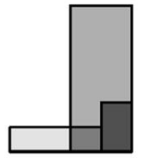

C

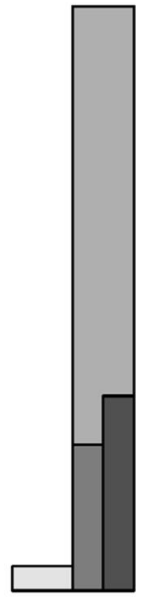

D run, c-concrete, w-wood, f-fresh wood, r-rotten wood (middle); number of exclusive taxa on each substrate type at each site (Site A to Site C) (right)

allocations patterns based on the substrate type are visible. Wood samples (fresh and rotten) are mainly distributed in the middle of the NMDS plot, with rotten wood samples being generally allocated within closer proximity to each other compared to the other substrate types. Concrete samples are generally oriented to the left side of the plot within each site group and rotten wood samples to the right. Fresh wood samples are generally oriented in between concrete and rotten wood samples.

Comparable results are obtained by the cluster analysis (see Fig. 12) identifying four distinct groups. One group comprises all substrate types from the two upstream investigation sites (A and $\mathrm{B}$ ), one the concrete samples from both lower investigation sites (C and D), one the fresh and rotten wood samples from site $\mathrm{C}$ and the last one both wood samples from site $\mathrm{D}$. The slight separation of the rotten wood samples at site $\mathrm{B}$ in the second cluster are mainly caused by distinctly higher invertebrate densities on the samples compared to those at sites A and B. Following the allocation of samples within the groups from the NMDS analysis, the cluster analysis shows a closer allocation of the concrete samples from site $\mathrm{C}$ and $\mathrm{D}$ to the samples of the first two sites A and B. 
Table 4 Overview of exclusive taxa (Type 1) and taxa significantly more abundant on concrete bars and fresh/rotten logs (Type 2)

\begin{tabular}{|c|c|c|c|c|c|}
\hline Order & Family & Genus & Species & Preference & Type \\
\hline \multirow[t]{6}{*}{ Coleoptera } & Corixidae & Corixidae & Gen. sp. & $\mathrm{C}$ & 1 \\
\hline & Dytiscidae & Dytiscidae & Gen. sp. & $\mathrm{R}$ & 1 \\
\hline & Elmidae & Esolus & sp. & $\mathrm{F}+\mathrm{R}$ & 1 \\
\hline & Elmidae & Macronychus & quadrituberculatus & $F+R$ & 1 \\
\hline & Gyrinidae & Orectochilus & villosus & $F+R$ & 1 \\
\hline & Hydraenidae & Hydraena* & sp.* & $\mathrm{R}$ & 2 \\
\hline Crustacea & Gammaridae* & Gammarus* & fossarum* & $\mathrm{R}$ & 2 \\
\hline \multirow[t]{3}{*}{ Diptera } & Empididae & Empididae & Gen. sp. & $\mathrm{R}$ & 1 \\
\hline & Psychodidae & Psychodidae & Gen. sp. & $\mathrm{R}$ & 1 \\
\hline & Tipulidae & Tipulidae & Gen. sp. & $\mathrm{R}$ & 1 \\
\hline \multirow[t]{6}{*}{ Ephemeroptera } & Ephemeridae & Ephemera & danica & $\mathrm{R}$ & 1 \\
\hline & Heptageniidae & Epeorus & alpicola & $\mathrm{C}$ & 1 \\
\hline & Heptageniidae & Heptagenia & coerulans & $\mathrm{R}$ & 1 \\
\hline & Heptageniidae & Heptagenia* & longicauda* & $F+R$ & 2 \\
\hline & Leptophlebiidae & Habroleptoides & sp. & $\mathrm{R}$ & 1 \\
\hline & Leptophlebiidae & Habrophlebia* & confusa* & $\mathrm{R}$ & 2 \\
\hline Mollusca & Tateidae & Potamopyrgus & antipodarum & $\mathrm{F}$ & 1 \\
\hline \multirow[t]{3}{*}{ Odonata } & Calopterygidae & Calopteryx & sp. & $\mathrm{F}$ & 1 \\
\hline & Gomphidae & Ophiogomphus & cecilia & $\mathrm{R}$ & 1 \\
\hline & Platycnemididae & Platycnemis & pennipes & $\mathrm{F}$ & 1 \\
\hline \multirow[t]{5}{*}{ Plecoptera } & Chloroperlidae & Chloroperla & sp. & $\mathrm{F}$ & 1 \\
\hline & Perlidae & Agnetina & elegantula & $F+R$ & 1 \\
\hline & Perlidae & Perla* & sp.* & $\mathrm{C}$ & 2 \\
\hline & Perlodidae* & Isoperla* & $\mathrm{sp}^{*}$ & $F+R$ & 2 \\
\hline & Taeniopterygidae & Rhabdiopteryx & navicula & $\mathrm{R}$ & 1 \\
\hline \multirow[t]{21}{*}{ Trichoptera } & Glossosomatidae & Glossosoma & sp. & $\mathrm{C}$ & 1 \\
\hline & Goeridae & Goera & pilosa & $\mathrm{R}$ & 1 \\
\hline & Goeridae & Silo & pallipes & $\mathrm{F}$ & 1 \\
\hline & Hydropsychidae & Hydropsyche & bulbifera & $\mathrm{F}$ & 1 \\
\hline & Hydropsychidae & Hydropsyche & dinarica & $\mathrm{F}+\mathrm{R}$ & 1 \\
\hline & Hydropsychidae & Hydropsyche & siltalai & $\mathrm{R}$ & 1 \\
\hline & Hydropsychidae* & & & $F+R$ & 2 \\
\hline & Hydroptilidae & Hydroptila & sp. & $\mathrm{F}$ & 1 \\
\hline & Lepidostomatidae* & Lepidostoma* & basale* & $F+R$ & 2 \\
\hline & Leptoceridae & Ceraclea & dissimilis & $\mathrm{R}$ & 1 \\
\hline & Leptoceridae & Ylodes & simulans & $\mathrm{R}$ & 1 \\
\hline & Limnephilidae* & Anabolia & furcata & $F+R$ & 1 \\
\hline & Limnephilidae* & Chaetopteryx & sp. & $F+R$ & 1 \\
\hline & Limnephilidae* & Halesus* & sp. $*$ & $F+R$ & 2 \\
\hline & Limnephilidae* & Melampophylax & melampus & $\mathrm{R}$ & 1 \\
\hline & Polycentropodidae & Cyrnus & trimaculatus & $\mathrm{F}$ & 1 \\
\hline & Polycentropodidae & Polycentropus & flavomaculatus & $\mathrm{R}$ & 1 \\
\hline & Psychomyiidae & Lype & phaeopa & $\mathrm{R}$ & 1 \\
\hline & Psychomyiidae & Psychomyia & pusilla & $F+R$ & 1 \\
\hline & Rhyacophilidae & Rhyacophila & s.str.sp.* & $F+R$ & 2 \\
\hline & Rhyacophilidae & Rhyacophila & tristis & $\mathrm{F}$ & 1 \\
\hline
\end{tabular}

* Marks the taxonomic level of a significant overrepresentation $(p \leq 0.05)$ 

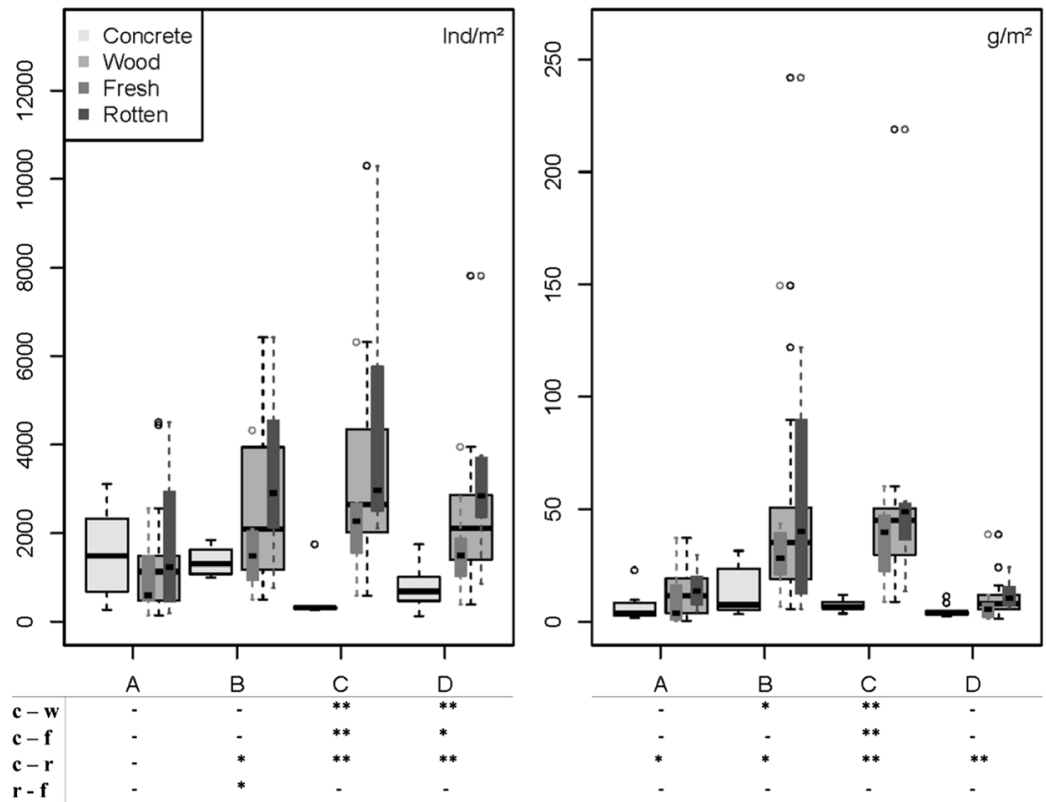

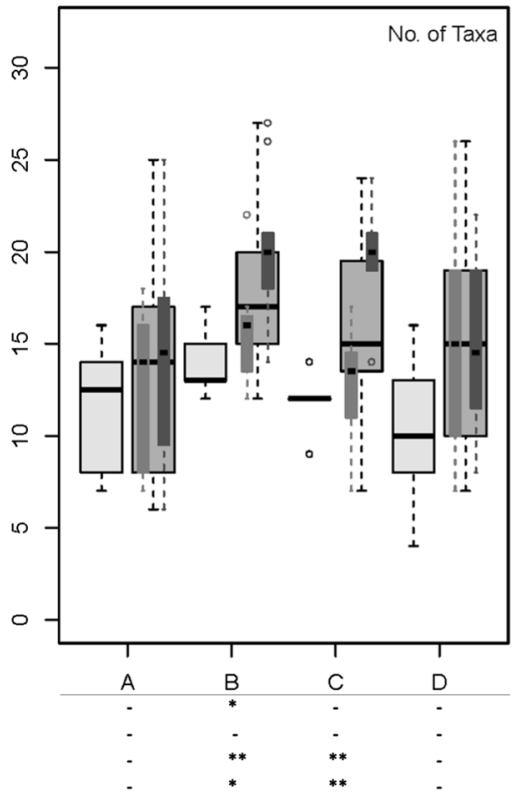

Fig. 10 Overview of the number of individuals and biomass per $\mathrm{m}^{2}$ as well as the number of taxa on each substrate type for each investigation site separately (a-d); significant differences between the substrate types are shown in the table below: $\mathrm{c}$ concrete, w-wood, f-fresh wood, $\mathrm{r}$-rotten wood; ${ }^{*} p \leq 0.05$, $* * p \leq 0.01,-p \geq 0.05$

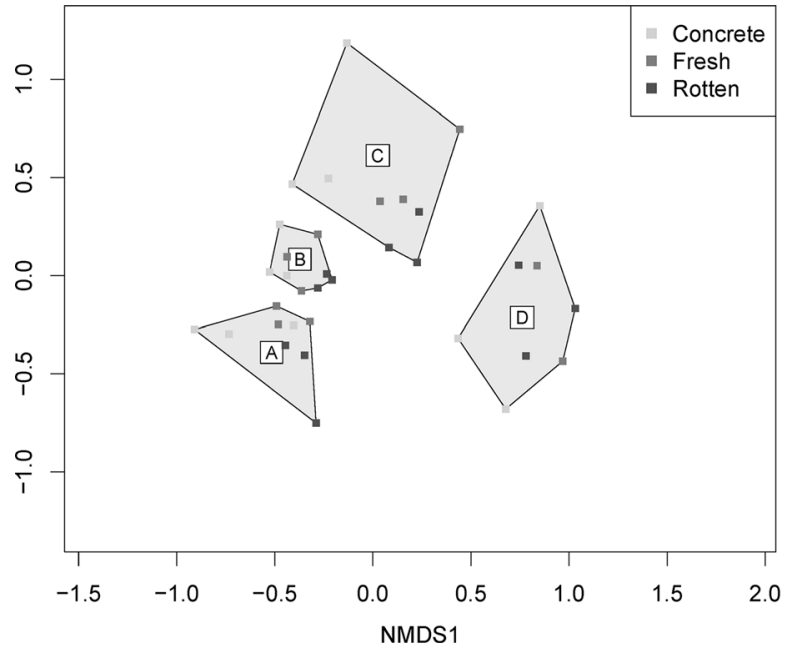

Fig. 11 Ordination graph of NMDS analysis based on the species composition and density from all concrete bars as well as fresh and rotten logs (sites A to D) (left) and display of species allocations in the ordination graph (right); species with best fit

Site-specific analysis

A site-specific approach gives comparable results to the pooled data. Abundance, biomass and taxa richness at each site and on each substrate type

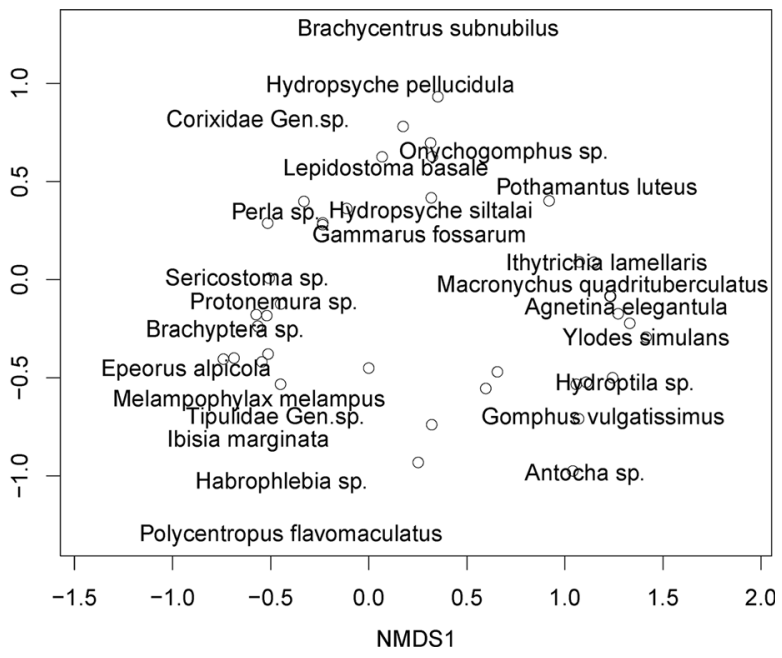

are shown by name; all other species are only indicated by solid circles to ensure readability; final stress for 2-dimensional solution $=0.1912$

consistently follow the patterns found in the overall dataset (see Fig. 10). Significant differences (Wilcoxon test: $*=0.05 ; * *=0.01)$ are shown in Fig. 10. Lowest values were generally found on concrete samples, followed by fresh and rotten wood samples. 


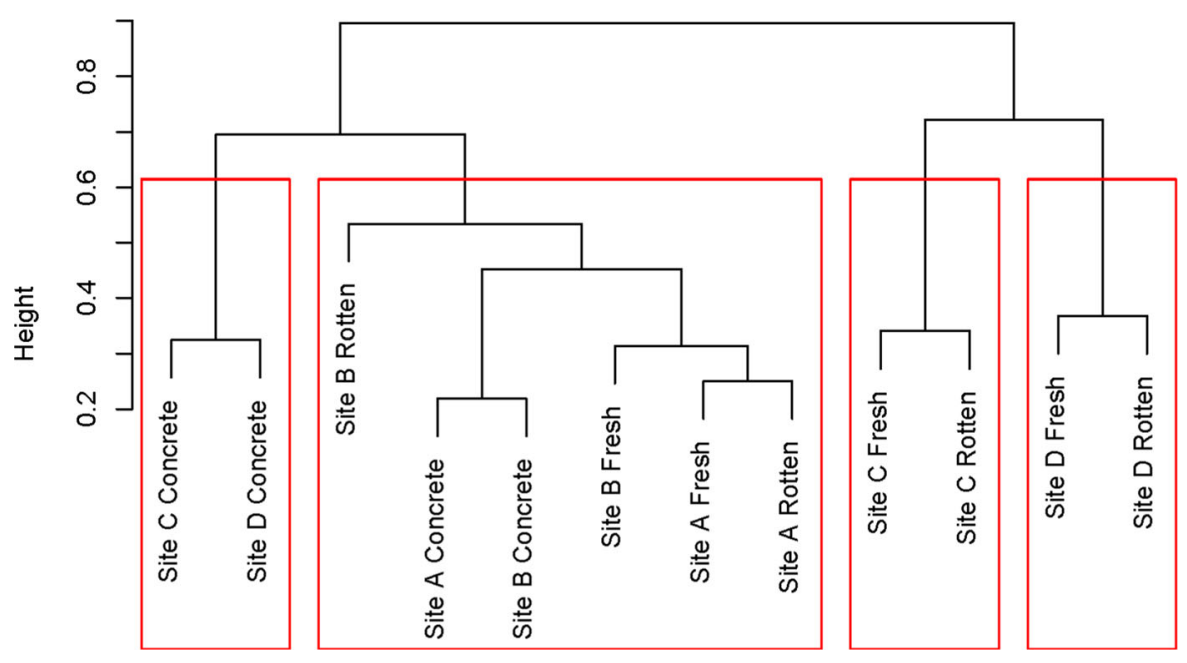

Fig. 12 Cluster dendrogram (distance measure: Bray-Curtis; group-linkage-method: Ward.D2) based on the species composition at each site (A-D)

One sole exception is evident at site A showing higher abundance on concrete than on wood samples. Highest abundance, biomass and taxa richness, regardless of the substrate types, were evident at the sites B and C. The most considerable colonization differences between the substrate types are evident at site $\mathrm{C}$.

The number of exclusive taxa found at each site is illustrated in Fig. 9 (right). Lowest values were consistently observed on concrete samples with only one exclusive taxon at site $\mathrm{A}, \mathrm{C}$ and $\mathrm{D}$ and none at site $B$. The number of exclusive wood taxa varies from site A to $\mathrm{C}$ between seven to ten taxa. At site $\mathrm{D}$, a considerably higher amount of 24 exclusive wood taxa was evident. Fresh wood samples mark an increase from three taxa at site $\mathrm{A}$ to six at site $\mathrm{D}$, while only one exclusive taxon was found at site B and C. On rotten wood samples, an increase of exclusive taxa from four at site $\mathrm{A}$ to eight at site $\mathrm{D}$ was found.

\section{Discussion}

Previous studies already stressed the general ecological importance of instream wood structures but most of them focused on naturally deposited logs or wood accumulations of varying sizes. Further, wood characteristics such as the state of decay received little attention. Detailed results varied greatly but nonetheless consistently showed higher benthic invertebrate densities and diversities on wood compared to adjacent lithal habitats (e.g., Benke et al. 1984; Smock et al. 1989, 1992; O'Connor 1991; Piegay and Gurnell 1997; Hoffmann and Hering 2000; Spänhoff et al. 2000; Grafahrend-Belau and Brunke 2005; Milner and Gloyne-Phillips 2005; Coe et al. 2009; Pilotto et al. 2016; Dossi et al. 2018).

The high variability of invertebrate density on wood is difficult to compare and interpret. Main reasons for these differences comprise the lack of a common experimental and quantification approach as well as general river types or regional differences (Benke and Wallace 2003). The aim of this study therefore was to assess the ecological significance of installed large wood compared to uniform concrete structures for benthic invertebrate communities, with particular attention on the wood condition. To overcome difficulties in the quantification of heterogenous instream LW pieces, we conducted our study with concrete, fresh and rotten LW of comparable size and shape.

Our results generally agree with the above-mentioned findings. A discrimination between lithal and xylal substrates showed distinctly higher benthic invertebrate density, biomass and diversity on xylal samples.

Besides similar patterns, the majority of the abovementioned studies reported higher invertebrate density on xylal substrates, especially considering those from North America (see Benke and Wallace 2003). A potential underestimation due to an insufficient 
exposition time can be ruled out in our study. Samples were exposed for 6 weeks and previous studies showed that colonization on installed substrates peaks at approximately two to 6 weeks the latest (e.g., Nilsen and Larimore 1973; O'Connor 1992; Spänhoff et al. 2000). Comparisons with a previously conducted study at the Lafnitz River, which focused on natural instream wood (see Dossi et al. 2018) further support our results. Recorded invertebrate density and biomass were on a comparable level but on average higher in the present study on the installed logs $\left(1655 \mathrm{Ind} / \mathrm{m}^{2} \mathrm{vs}\right.$. $2437 \mathrm{Ind} / \mathrm{m}^{2} ; 19.2 \mathrm{~g} / \mathrm{m}^{2}$ vs. $\left.29.6 \mathrm{~g} / \mathrm{m}^{2}\right)$. Similar differences between installed and natural substrates have already been observed and discussed. While Spänhoff and Cleven (2010) generally referred to rapid initial colonization processes of newly introduced substrates resulting in above-average invertebrate densities in the first weeks, Spänhoff et al. (2000) added another aspect that was also observed in the Lafnitz River. Due to the longer residence time of naturally deposited, compared to installed logs, larger parts of their surface tend to be covered by sediments which are therefore not (or only partially) suitable for benthic invertebrate colonization. That affects surface density calculations and leads to a slight underestimation of benthic invertebrate abundance on naturally deposited logs.

Site characteristics and the natural longitudinal zonation of aquatic communities along the river course were identified as the dominant factor governing the overall composition of the benthic invertebrate community. However, overall species richness and density of invertebrates further depended on the wood condition as already indicated by previous studies (e.g., Magoulick 1998; Spänhoff et al. 2000). An additional distinction of our samples between different substrates revealed discrete benthic invertebrate density and diversity differences, with lowest values on concrete, followed by fresh and peak values on rotten wood. Only at site A, no clear differences were evident between the substrate types, which emphasizes the results of Dossi et al. (2018). Their study showed that the importance of LW as unique habitat structure significantly changes along the longitudinal gradient of a river. While invertebrate species showed no significant preference for a specific substrate type in upper river sections, an increasing diversification of the benthic communities among xylal and lithal substrates was evident along the river course.
Information on determining factors of specific benthic invertebrate colonization patterns on logs of different decay stages is still sparse, but the results of previous studies suggest that wood surface characteristics present a decisive aspect (e.g., Kaufman and King 1987; O’Connor 1991; Phillips 1993; Phillips and Kilambi 1994; Magoulick 1998; Spänhoff et al. 2000). LW further develops a productive epixylic biofilm which is an essential food source for grazing taxa (Golladay and Sinsabaugh 1991; Sinsabaugh et al. 1991), which might depend on log surface characteristics. Conditioned wood has a softer and more diverse, 3-dimensional, structure compared to most other habitats. It therefore provides a comparably large, smooth and more importantly complex habitat on a small spatial scale compared to rocks and fresh LW which is potentially beneficial for benthic invertebrate colonization (Kaufman and King 1987; O'Connor 1991; Magoulick 1998). The consistently higher densities and diversities on rotten logs compared to fresh logs and concrete bars support these assumptions. Besides overall quantities, consistent statements on taxa-specific colonization patterns are only possible to a limited extend. Even though most taxa were found in higher quantities on rotten wood, only a few taxa showed significant preferences. The most prominent differences were found for $G$. fossarum being significantly more abundant on rotten logs. G. fossarum being a shredder with preferences for low flow velocities might benefit most from the more complex surface structure of rotten wood. It provides flow protection as well as retention areas for organic matter on a small spatial scale. The softer surface might further facilitate the fragmentation and processing of the woody material itself as well as epixylic biofilm growth. Most taxa labeled as closely associated to wood such as L. basale, M. quadrituberculatus, O. villosus or A. elegantula (Anderson et al. 1978; Hoffmann and Hering 2000; Dossi et al. 2018) were found to be significantly more abundant on wood but did not show any preference for either fresh or rotten logs. Assumptions on possible differences due to varying biofilm developments on the tested substrate types could not be verified. Grazer taxa were equally dominant on the tested substrate types.

Our results further show that artificial LW introduction, even of comparably small logs as used in our study, comprise a valuable element in river restoration measures. All samples were consistently colonized by 
heterogenous invertebrate taxa throughout the sampling period and also threatened or rare species, closely associated to wood (e.g., M. quadrituberculatus, H. longicauda; A. elegantula), were frequently found on the installed logs (Graf 1997; Bauernfeind and Humpesch 2001; Graf and Kovacs 2002; Jäch et al. 2005; Buffagni et al. 2016).

Our results emphasize that not only the presence of LW is of importance. The suitability as a habitat significantly depends on the state of decay. That relates to two important, interrelated aspects, specifically the residence time of logs in stream channels and the species of wood. While residence time and the state of decay are clearly connected, species of wood may be decisive as well. Besides possible colonization preferences for certain wood species, differing degradation rates (Spänhoff and Meyer 2004) and thus variations of the required residence time in rivers add another scale to the research topic. These findings are of particular importance considering management actions like the large-scale removal of instream LW, which deprived rivers from an essential structural element and habitat and significant changes of riparian vegetation communities (Hering et al. 2000; Hohensinner et al. 2013). Given these initial insights on the effect of wood quality on benthic invertebrate colonization patterns further research incorporating also the species of wood becomes of particular interest. Wood species-specific properties (e.g., firmness, structure, texture, stability, chemical composition) and subsequent varying degradation and habitat characteristics will be investigated in a follow-up research.

Acknowledgements Open access funding provided by University of Natural Resources and Life Sciences Vienna (BOKU).

Open Access This article is licensed under a Creative Commons Attribution 4.0 International License, which permits use, sharing, adaptation, distribution and reproduction in any medium or format, as long as you give appropriate credit to the original author(s) and the source, provide a link to the Creative Commons licence, and indicate if changes were made. The images or other third party material in this article are included in the article's Creative Commons licence, unless indicated otherwise in a credit line to the material. If material is not included in the article's Creative Commons licence and your intended use is not permitted by statutory regulation or exceeds the permitted use, you will need to obtain permission directly from the copyright holder. To view a copy of this licence, visit http://creativecommons.org/licenses/by/4.0/.

\section{Annex}

See Tables 5, 6 and 7.

Table 5 Overview of decay categories; decay class: decay category according to Robinson and Beschta (1990)

\begin{tabular}{lllllll}
\hline Decay class & Bark & Twigs & Surface texture & Shape & Wood color & State \\
\hline 1 & Intact & Present & Intact/firm & Round & Original & n \\
2 & Intact & Absent & Intact/firm & Round & Original & $\mathrm{n}$ \\
3 & Trace & Absent & Smooth to some surface abrasion & Round & Original to darkening & $\mathrm{n}$ \\
4 & Absent & Absent & Abrasion to some holes and openings & Round to oval & Dark & $\mathrm{d}$ \\
5 & Absent & Absent & Vesicular with many holes and openings & Irregular & Dark & $\mathrm{d}$ \\
\hline
\end{tabular}

$n$ not decayed, $d$ decayed

Table 6 Overview of decay categories; decay class: decay category according to Grette (1985)

$N$ not decayed, $d$ decayed

\begin{tabular}{llllll}
\hline Decay class & Bark & Limbs & Surface texture & Center & State \\
\hline 1 & Intact & Present & Firm & Solid & $\mathrm{n}$ \\
2 & Intact & Absent & Firm & Solid & $\mathrm{n}$ \\
3 & Loose or absent & Absent & Firm & Solid & $\mathrm{n}$ \\
4 & Absent & Absent & Slightly rottend & Solid & $\mathrm{n}$ \\
5 & Absent & Absent & Extensively rottend & Solid & $\mathrm{d}$ \\
6 & Absent & Absent & Completely rottend & Solid & $\mathrm{d}$ \\
7 & Absent & Absent & Completely rottend & Rotted & $\mathrm{d}$ \\
\hline
\end{tabular}


Table 7 Taxalist of all taxa found at all four sites; "c" — concrete bars, "f"— fresh logs, "r" - rotten logs

\begin{tabular}{|c|c|c|c|c|c|}
\hline Order & Family & Taxon & $\mathrm{c}$ & f & $\mathrm{r}$ \\
\hline Turbellaria & Turbellaria & Turbellaria Gen.sp. & $*$ & $*$ & * \\
\hline Gastropoda & Hydrobiidae & Potamopyrgus antipodarum (J.E. Gray, 1843) & - & $*$ & - \\
\hline Oligochaeta & Oligochaeta & Oligochaeta Gen.sp. & $*$ & $*$ & * \\
\hline \multirow[t]{2}{*}{ Amphipoda } & Corophiidae & Corophium sp. & - & $*$ & - \\
\hline & Gammaridae & Gammarus fossarum Koch, 1835 & $*$ & $*$ & * \\
\hline Hydrachnidia & Hydrachnidia & Hydrachnidia Gen.sp. & $*$ & * & * \\
\hline \multirow[t]{24}{*}{ Ephemeroptera } & Baetidae & Baetis sp. & $*$ & $*$ & * \\
\hline & Caenidae & Caenis sp. & - & $*$ & - \\
\hline & \multirow[t]{4}{*}{ Ephemerellidae } & Ephemerella ignita (Poda, 1761) & $*$ & $*$ & * \\
\hline & & Ephemerella mucronata (Bengtsson, 1909) & $*$ & $*$ & $*$ \\
\hline & & Ephemerella notata Eaton, 1887 & $*$ & $*$ & * \\
\hline & & Ephemerella sp. & $*$ & $*$ & * \\
\hline & Ephemeridae & Ephemera danica Müller, 1764 & - & - & * \\
\hline & \multirow[t]{11}{*}{ Heptageniidae } & Ecdyonurus sp. & $*$ & $*$ & * \\
\hline & & Electrogena sp. & - & $*$ & - \\
\hline & & Epeorus alpicola (Eaton, 1871) & $*$ & - & - \\
\hline & & Epeorus assimilis (Eaton, 1871) & $*$ & $*$ & * \\
\hline & & Heptagenia coerulans Rostock, 1877 & - & - & * \\
\hline & & Heptagenia flava Rostock, 1877 & $*$ & * & * \\
\hline & & Heptagenia longicauda (Stephens, 1836) & $*$ & $*$ & * \\
\hline & & Heptagenia sp. & $*$ & $*$ & * \\
\hline & & Heptagenia sulphurea (Müller, 1776) & $*$ & $*$ & * \\
\hline & & Heptageniidae Gen.sp. & $*$ & $*$ & $*$ \\
\hline & & Rhithrogena sp. & $*$ & * & * \\
\hline & \multirow[t]{4}{*}{ Leptophlebiidae } & Habroleptoides sp. & - & - & $*$ \\
\hline & & Habroleptoides confusa Sartori \& Jacob, 1986 & - & - & $*$ \\
\hline & & Habrophlebia sp. & - & * & * \\
\hline & & Paraleptophlebia sp. & - & $*$ & $*$ \\
\hline & Oligoneuriidae & Oligoneuriella rhenana (Imhoff, 1852) & $*$ & $*$ & $*$ \\
\hline & Potamanthidae & Pothamantus luteus (Linnaeus, 1767) & $*$ & * & - \\
\hline \multirow[t]{5}{*}{ Odonata } & Calopterygidae & Calopteryx sp. & - & $*$ & - \\
\hline & \multirow[t]{3}{*}{ Gomphidae } & Gomphus vulgatissimus (Linnaeus, 1758) & $*$ & * & - \\
\hline & & Onychogomphus sp. & $*$ & * & - \\
\hline & & Ophiogomphus cecilia (Geoffroy In Fourcroy, 1785) & - & - & $*$ \\
\hline & Platycnemididae & Platycnemis pennipes (Pallas, 1771) & - & $*$ & - \\
\hline \multirow[t]{10}{*}{ Plecoptera } & \multirow[t]{2}{*}{ Chloroperlidae } & Chloroperla sp. & - & $*$ & - \\
\hline & & Siphonoperla sp. & $*$ & $*$ & $*$ \\
\hline & Leuctridae & Leuctra sp. & $*$ & * & $*$ \\
\hline & \multirow[t]{3}{*}{ Nemouridae } & Amphinemura sp. & $*$ & $*$ & $*$ \\
\hline & & Nemoura/Nemurella sp. & $*$ & $*$ & $*$ \\
\hline & & Protonemura sp. & $*$ & $*$ & $*$ \\
\hline & \multirow[t]{4}{*}{ Perlidae } & Agnetina elegantula (Klapalek, 1905) & - & $*$ & $*$ \\
\hline & & Dinocras sp. & $*$ & $*$ & $*$ \\
\hline & & Perla sp. & $*$ & $*$ & $*$ \\
\hline & & Perlidae Gen.sp. & - & $*$ & $*$ \\
\hline
\end{tabular}


Table 7 continued

\begin{tabular}{|c|c|c|c|c|c|}
\hline Order & Family & Taxon & $\mathrm{c}$ & $\mathrm{f}$ & $\mathrm{r}$ \\
\hline & Perlodidae & Isoperla $\mathrm{sp}$. & $*$ & $*$ & $*$ \\
\hline & & Perlodes sp. & $*$ & $*$ & $*$ \\
\hline & Taeniopterygidae & Brachyptera risi (Morton, 1896) & $*$ & $*$ & $*$ \\
\hline & & Brachyptera seticornis (Klapalek, 1902) & $*$ & $*$ & * \\
\hline & & Brachyptera sp. & $*$ & $*$ & $*$ \\
\hline & & Rhabdiopteryx navicula Theischinger, 1974 & - & - & $*$ \\
\hline \multirow[t]{2}{*}{ Heteroptera } & Aphelocheiridae & Aphelocheirus aestivalis (Fabricius, 1803) & $*$ & - & $*$ \\
\hline & Corixidae & Corixidae Gen.sp. & $*$ & - & - \\
\hline \multirow[t]{10}{*}{ Coleoptera } & Dryopidae & Pomatinus sp. & - & - & $*$ \\
\hline & Dytiscidae & Dytiscidae Gen.sp. & - & - & * \\
\hline & Elmidae & Elmidae Gen.sp. & - & - & $*$ \\
\hline & & Elmis sp. & $*$ & $*$ & $*$ \\
\hline & & Esolus sp. & - & * & $*$ \\
\hline & & Limnius sp. & $*$ & $*$ & $*$ \\
\hline & & Macronychus quadrituberculatus Müller, 1806 & - & * & $*$ \\
\hline & Gyrinidae & Orectochilus villosus (Müller, 1776) & - & $*$ & $*$ \\
\hline & Helophoridae & Helophorus sp. & - & $*$ & $*$ \\
\hline & Hydraenidae & Hydraena sp. & $*$ & $*$ & $*$ \\
\hline \multirow[t]{27}{*}{ Trichoptera } & Brachycentridae & Brachycentrus subnubilus Curtis, 1834 & $*$ & $*$ & $*$ \\
\hline & Glossosomatidae & Glossosoma conformis Neboiss, 1963 & $*$ & - & * \\
\hline & & Glossosoma sp. & $*$ & - & - \\
\hline & Goeridae & Goera pilosa (Fabricius, 1775) & - & - & $*$ \\
\hline & & Goeridae sp. & $*$ & $*$ & - \\
\hline & & Silo pallipes (Fabricius, 1781) & $*$ & $*$ & - \\
\hline & Hydropsychidae & Cheumatopsyche lepida (Pictet, 1834) & $*$ & - & * \\
\hline & & Hydropsyche bulbifera Mclachlan, 1878 & - & $*$ & - \\
\hline & & Hydropsyche dinarica Marinkovic, 1979 & - & $*$ & $*$ \\
\hline & & Hydropsyche instabilis (Curtis, 1834) & $*$ & $*$ & $*$ \\
\hline & & Hydropsyche pellucidula (Curtis, 1834) & $*$ & * & $*$ \\
\hline & & Hydropsyche siltalai Döhler, 1963 & - & $*$ & $*$ \\
\hline & & Hydropsyche sp. & $*$ & * & * \\
\hline & Hydroptilidae & Hydroptila sp. & - & $*$ & - \\
\hline & & Ithytrichia lamellaris Eaton, 1873 & $*$ & $*$ & $*$ \\
\hline & Lepidostomatidae & Lepidostoma basale (Kolenati, 1848) & $*$ & $*$ & * \\
\hline & Leptoceridae & Ceraclea dissimilis (Stephens, 1836) & - & - & $*$ \\
\hline & & Leptoceridae Gen.sp. & - & $*$ & * \\
\hline & & Ylodes simulans (Tjeder, 1929) & - & - & $*$ \\
\hline & Limnephilidae & Allogamus auricollis (Pictet, 1834) & $*$ & * & * \\
\hline & & Anabolia furcata Brauer, 1857 & - & $*$ & $*$ \\
\hline & & Chaetopteryx fusca Brauer, 1857 & - & * & $*$ \\
\hline & & Chaetopteryx sp. & - & $*$ & $*$ \\
\hline & & Halesus sp. & $*$ & * & $*$ \\
\hline & & Limnephilidae Gen.sp. & $*$ & $*$ & * \\
\hline & & Melampophylax melampus (McLachlan, 1867) & - & - & $*$ \\
\hline & & Potamophylax cingulatus (Stephens, 1837) & $*$ & * & * \\
\hline
\end{tabular}


Table 7 continued

\begin{tabular}{|c|c|c|c|c|c|}
\hline Order & Family & Taxon & $\mathrm{c}$ & f & $\mathrm{r}$ \\
\hline & & Potamophylax rotundipennis (Brauer, 1857) & $*$ & $*$ & $*$ \\
\hline & Odontoceridae & Odontocerum albicorne (Scopoli, 1763) & $*$ & $*$ & $*$ \\
\hline & Polycentropodidae & Cyrnus trimaculatus (Curtis, 1834) & - & $*$ & - \\
\hline & Polycetropodidae & Polycentropus flavomaculatus (Pictet, 1834) & - & - & * \\
\hline & Psychomyiidae & Lype phaeopa (Stephens, 1936) & - & - & * \\
\hline & & Psychomyia pusilla (Fabricius, 1781) & - & $*$ & $*$ \\
\hline & Rhyacophilidae & Rhyacophila s.str.sp. & $*$ & $*$ & $*$ \\
\hline & & Rhyacophila tristis Pictet, 1834 & - & $*$ & - \\
\hline & Sericostomatidae & Sericostoma sp. & $*$ & $*$ & $*$ \\
\hline \multirow[t]{12}{*}{ Diptera } & Athericidae & Ibisia marginata (Fabricius, 1781) & $*$ & $*$ & * \\
\hline & Ceratopogonidae & Bezzia-Gruppe sp. & - & $*$ & - \\
\hline & Chironomidae & Chironomidae Gen.sp. & $*$ & $*$ & $*$ \\
\hline & Empididae & Empididae Gen.sp. & - & $*$ & $*$ \\
\hline & Limoniidae & Antocha sp. & $*$ & $*$ & - \\
\hline & & Hexatoma sp. & $*$ & $*$ & $*$ \\
\hline & $\begin{array}{r}\text { Limoniidae/ } \\
\text { Pediciidae }\end{array}$ & Limoniidae Gen.sp. & - & $*$ & $*$ \\
\hline & Pediciidae & Dicranota sp. & $*$ & $*$ & $*$ \\
\hline & Psychodidae & Psychodidae Gen.sp. & - & - & $*$ \\
\hline & Simuliidae & Prosimulium sp. & - & $*$ & - \\
\hline & & Simulium sp. & $*$ & $*$ & $*$ \\
\hline & Tipulidae & Tipulidae Gen.sp. & - & - & $*$ \\
\hline
\end{tabular}

*Present, - absent

\section{References}

Anderson NH, Sedell JR, Roberts LM, Triska FFJ (1978) The role of aquatic invertebrates in processing of wood debris in coniferous forest streams. Am Midland Nat 100:64-82

AQEM Consortium (2002) Manual for the application of the AQEM system. A comprehensive method to assess european streams using benthic macroinvertebrates, developed for the purpose of the Water Framework Directive

Bauernfeind E, Humpesch U (2001). Die Eintagsfliegen Zentraleuropas (Insecta: Ephemeroptera): Bestimmung und Ökologie. Verlag des Naturhistorischen Museums Wien, pp 1-239

Benke AC (1998) Production dynamics of riverine chironomids (Diptera): extremely high biomass turnover rates of primary consumers. Ecology 79:899-910

Benke AC, Wallace JB (2003) Influence of wood on invertebrate communities in streams and rivers wood-created habitat. Am Fish Soc Symp 37:149-177

Benke AC, Van Arsdall TC, Gillespie DM, Parish FK (1984) Invertebrate productivity in a subtropical blackwater river: the importance of habitat and life history. Ecol Monogr 54:25-63

Bilby RE, Bisson PA (1998) Function and distribution of large woody debris. In: Naiman RJ, Bilby RE (eds) River ecology and management. Springer, New York, pp 324-346
Blanckaert KJF, Han R, Pilotto F, Pusch MT (2014) Effects of large wood on morphology, flow and turbulence in a lowland river. Proc Int Conf Fluvial Hydraul River Flow 2014:2493-2501

BMLFUW (2002) Gewässerschutzbericht 2002. Bundesministeriums für Land- und Forstwirtschaft, Umwelt und Wasserwirtschaft, Wien

Buffagni A, Armanini DG, Cazzola M, Alba-Tercedor J, LópezRodríguez MJ, Murphy J, Sandin L, Schmidt-Kloiber A (2016) Dataset "Ephemeroptera". www. freshwaterecology.info. The taxa and autecology database for freshwater organisms, version 6.0. Accessed 23 July 2019

Cejka A, Dvorak M, Korner I, Fortmann I, Knogler E, Korner I et al. (2005): Das Lafnitztal. Flusslandschaft im Herzen Europas. Publikationen des Umweltbundesamtes, NWV Verlag; 1 edition (15 April 2005), Wien

Coe HJ, Kiffney PM, Pess GR, Kloehn KK, MCHenry ML (2009) Periphyton and invertebrate response to wood placement in large pacific coastal rivers. River Res Appl 25:1025-1035

Copp G (1992) Comparative microhabitat use of cyprinid larvae and juveniles in a lotic floodplain channel. Environ Biol Fishes 33:181-193

Dossi F, Leitner P, Pauls S, Graf W (2018) In the mood for wood-habitat specific colonization patterns of benthic 
invertebrate communities along the longitudinal gradient of an Austrian river. Hydrobiologia 805:1-14

Dudley T, Anderson NH (1982) A survey of invertebrates associated with wood debris in aquatic habitats. Melanderia 39(1):21

Dufrene M, Legendre P (1997) Species assemblages and indicator species: the need for a flexible asymmetrical approach. Ecol Monogr 67:345-366

Flores L, Larrañaga A, Díez JR, Elosegi A (2011) Experimental wood addition in streams: effects on organic matter storage and breakdown. Freshw Biol 56(10):2156-2167

Golladay S, Sinsabaugh R (1991) Biofilm development on leaf and wood surfaces in a boreal river. Freshw Biol 25:437-450

Graf W (1997) A new record of the perlid stonefly Agnetina elegantula (Klapalek, 1905) in Europe. In: Landolt P, Sartori M (eds) Ephemeroptera \& Plecoptera: Biology Ecology - Systematics. MTL Fribourg, pp 205-208

Graf W, Kovacs T (2002) The aquatic invertebrates of the Lafnitz-Raba river system in Austria and Hungary: a natural heritage of the Central European Potamocoen. Internat Assoc Danube Res 34:295-301

Grafahrend-Belau E, Brunke M (2005) Die Besiedlung von Totholz und anderen Sohlsubstraten der unteren Mulde und mittleren Elbe durch aquatisch lebende Wirbellose. Naturschutz im Land Sachsen Anhalt 42:13-24

Grette GB (1985) The abundance and role of large organic debris in juvenile salmonid habitat in streams in second growth and unlogged forests. Master Thesis, University of Washington, Seattle, WA

Gurnell AM, Gregory KJ, Petts GE (1995) The role of coarse woody debris in forest aquatic habitats: implications for management. Aquat Conserv Mar Freshw Ecosyst 5:143-166

Gurnell AM, Tockner K, Edwards PJ, Petts GE (2005) Effects of deposited wood on biocomplexity of river corridors. Front Ecol Environ 3(7):377-382

Hering D, Reich M (1997) Bedeutung von Totholz für Morphologie, Besiedlung und Renaturierung mitteleuropäischer Fließgewässer. Natur Und Landschaft 72(9):383-390

Hering D, Kail J, Eckert S, Gerhard M, Meyer E, Mutz M, Reich M, Weiss I (2000) Coarse woody debris quantity and distribution in Central European streams. Int Rev Hydrobiol $85: 5-23$

Hoffmann A, Hering D (2000) Wood-associated macroinvertebrate fauna in Central European Streams. Int Rev Hydrobiol 85:25-48

Hohensinner S, Drescher A, Eckmüllner O, Egger G, Gierlinger S, Hager H, Haidvogl G, Jungwirth M (2013) Genug Holz für Stadt und Fluss? Wiens Holzressourcen in dynamischen Donau-Auen (Enough wood for city and river? Vienna's wood resources in dynamic Danube floodplain). Verlag Guthmann-Peterson, Wien

Illies J (1978) Limnofauna Europaea. Gustav Fisher Verlag, pp $1-532$

Jäch M, Dietrich F, Raunig B (2005) Rote Liste der Zwergwasserkäfer (Hydraenidae) und Krallenkäfer (Elmidae) Österreichs (Insecta: Coleoptera): 211-284 In: Spitzenberger F, Frühauf J, Berg H, Zechner L, Jäch M, Dietrich F, Gepp J, Höttinger H (2005) Rote Liste gefährdeter Tiere Österreichs
Kail J, Hering D (2005) Using large wood to restore streams in central europe: potential use and likely effects. Landsc Ecol 20(6):755-772

Kail J, Hering D, Muhar S, Gerhard M, Preis S (2007) The use of large wood in stream restoration: experiences from 50 projects in Germany and Austria. J Appl Ecol 44(6):1145-1155

Kaufman MG, King RH (1987) Colonization of wood substrates by the aquatic xylophage Xylotopus Par (Diptera: Chironomidae) and a description of its life history. Can J Zool 65:2280-2286

Kruskal JB (1964) Multidimensional scaling by optimizing goodness of fit to a nonnumeric hypothesis. Psychometrical 29:1-27

Magoulick DD (1998) Effect of wood hardness, condition, texture and substrate type on community structure of stream invertebrates. Am Midl Nat 139(2):187-200

Manners RB, Doyle MW, Small MJ (2007) Structure and hydraulics of natural woody debris jams. Water Resour Res 43:1-17

Mckie BG, Cranston P (1998) Keystone coleopterans? Colonization by wood-feeding elmids of experimentally immersed woods in south-eastern Australia. Mar Freshw Res 49:79-88

Milner AM, Gloyne-Phillips IT (2005) The role of riparian vegetation and woody debris in the development of macroinvertebrate assemblages in streams. River Res Appl 21:403-420

Minshall GW (1984) Aquatic insect-substratum relationships: 358-400. In: Resh VH, Rosenberg DM (eds) The ecology of aquatic insects. Praeger Scientific, New York

Mutz M (2003) Hydraulic effects of wood in streams and rivers. Am Fish Soc Symp 37:93-107

Nilsen HC, Larimore RW (1973) Establishment of invertebrate communities on log substrates in the Kaskasia river, Illinois. Ecology 54:367-374

O'Connor NA (1991) The effects of habitat complexity on the macroinvertebrates colonizing wood substrate in a lowland stream. Oecologia 85:504-512

O'Connor NA (1992) Quantification of submerged wood in a lowland Australian stream system. Freshw Biol 27:387-395

Ofenböck T, Moog O, Hartmann A, Stubauer I (2010) Leitfaden zur Erhebung der biologischen Qualitätselemente, Teil A2-Makrozoobenthos. Bundesministerium für Nachhaltigkeit und Tourismus, Wien

Phillips EC (1993) Aquatic insects and fishes associated with coarse woody debris in northwest Arkansas streams. Ph. D. Diss. University of Arkansas

Phillips EC, Kilambi RV (1994) Use of coarse woody debris by Diptera in Ozark streams, Arizona. J N Am Benth Soc 13:151-159

Piegay H, Gurnell AM (1997) Large woody debris and river geomorphological patter: examples from S.E. France and S. England. Geomorphology 19:99-116

Pilotto F, Bertoncin A, Harvey GL, Wharton G, Pusch MT (2014) Diversification of stream invertebrate communities by large wood. Freshw Biol 59:2571-2583

Pilotto F, Harvey GL, Wharton G, Pusch MT (2016) Simple large wood structures promote hydromorphological 
heterogeneity and benthic macroinvertebrate diversity in low-gradient rivers. Aquat Sci 24:1-12

Rabeni CF, Hoel SM (2000) The importance of woody debris to benthic invertebrates in two Missouri prairie streams. Verhandlungen: Internationale Vereinigung für Theoretische und Angewandte Limnologie 27:1499-1502

Robinson EG, Beschta RL (1990) Characteristics of coarse woody debris for several coastal streams of southeast Alaska, USA. Can J Fish Aquat Sci 47:1684-1694

Shields FD, Morin N, Kuhnle RA (2001) Effect of large woody debris structures on stream hydraulics. In: Proceedings of the conference on wetland engineering and river restoration, Reno, Nevada. 27-31 August 2001

Sinsabaugh RL, Golladay S, Linkins A (1991) Comparison of epilithic and epixylic biofilm development in a boreal river. Freshw Biol 25:179-187

Smith LC, Smock LA (1992) Ecology of invertebrate predators in a coastal plain stream. Freshw Biol 28:319-329

Smock LA, Metzler GM, Gladden JE (1989) Role of debris jams in the structure and function of low-gradient headwater streams. Ecology 70:764-775

Smock LA, Gladden JE, Riekenberg JL, Smith LC, Black CR (1992) Lotic macroinvertebrate production in three dimensions: channel surface, hyporheic, and floodplain environments. Ecology 73:876-886

Spänhoff B, Cleven E (2010) Wood in different stream types: Epixylic biofilm and wood-inhabiting invertebrates in a lowland versus an upland stream. Ann Limnol 46:169-179

Spänhoff B, Meyer EI (2004) Breakdown rates of wood in streams. J N Am Benthol Soc 23:189-197

Spänhoff B, Alecke C, Meyer EI (2000) Colonization of submerged twigs and branches of different wood genera by aquatic macroinvertebrates. Int Rev Hydrobiol 85:49-66

Strahler AN (1957) Quantitative analysis of watershed geomorphology. Trans Am Geophys Union 38:913-920

Sweeney BW (1993) Effects of streamside vegetation on macroinvertebrate communities of White Clay Creek in Eastern North America. Proc Acad Nat Sci Phil 144:291-340

Publisher's Note Springer Nature remains neutral with regard to jurisdictional claims in published maps and institutional affiliations. 